\title{
Sivas İlinin Farklı İlçelerinde Şebeke Bağlantılı Güneş Enerji Santrallerinin Tasarımı ve Analizi
}

\author{
Vekil Sari $^{{ }^{*}}$, Fatih Yavuz Özyiğit ${ }^{2}$ \\ 1* Sivas Cumhuriyet Üniversitesi, Mühendislik Fakültesi, Elektrik Elektronik Mühendisliği Bölümü, Sivas, Türkiye, (ORCID: 0000-0001-5963-0179), \\ vsari@cumhuriyet.edu.tr \\ ${ }^{2}$ Sivas Cumhuriyet Üniversitesi, Fen Bilimleri Enstitüsü, Enerji Bilimi ve Teknolojisi Mühendisliği Bölümü, Sivas, Türkiye, (ORCID: 0000-0003-0417-6890), \\ yavuz.ozygt@gmail.com
}

(İlk Geliş Tarihi 2 Eylül 2020 ve Kabul Tarihi 25 Ekim 2020)

(DOI: $10.31590 /$ ejosat.797434)

ATIF/REFERENCE: Sarı, V. \& Özyiğit, F. Y. (2020). Sivas İlinin Farklı İlçelerinde Şebeke Bağlantılı Güneş Enerji Santrallerinin Tasarımı ve Analizi. Avrupa Bilim ve Teknoloji Dergisi, (20), 425-437.

\section{$\ddot{O} \mathbf{z}$}

Fosil yakıtların azalması ve çevre kirliliğine sebep olması nedeniyle yenilenebilir enerjiden elektrik enerjisi üretiminin önemi son yıllarda artmıştır. Buna bağlı olarak dünyada ve ülkemizde kurulan rüzgâr ve güneş enerji santrallerinin sayısı da gittikçe artmaktadır. Ülkemiz güneş enerjisi bakımından oldukça verimli bir konuma sahiptir. Bu yüzden bu alanda birçok çalışma yapılmaktadır. Bu çalışmada Sivas ilinin 5 ilçesinde kurulu gücü $10 \mathrm{MW}$ olan monokristal paneller ve kurulu gücü 9,999 MW olan polikristal paneller kullanılarak toplam 10 adet güneş enerjisi santrali tasarımı ve analizi gerçekleştirilmiştir. Kullanılan paneller sabit eğik sistem olarak tasarlanmış, panel eğim açısı $35^{\circ}$ ve azimuth açısı $0^{\circ}$ olarak konumlandırılmıştır. Monokristal sistem tasarımında 290 Watt gücünde 34.482 adet panel ve $72 \mathrm{~kW}$ ' lık 148 adet invertör kullanılmıştır. Paneller 21 adet seri ve 1.642 adet paralel olacak şekilde bağlanmıştır. Modüllerin toplam alanı $56.440 \mathrm{~m}^{2}$ dir. Polikristal sistem tasarımında 290 Watt' lık 34.480 adet panel ve $72 \mathrm{~kW}$ ' lik 148 adet invertör kullanılmıştır. Paneller 20 adet seri ve 1.724 adet paralel olacak şekilde bağlanmıştır. Modüllerin toplam alanı $66.161 \mathrm{~m}^{2}$ dir. Sistem tasarımı için Trina Solar markasının monokristal panelleri ve Canadian Solar firmasının polikristal panelleri seçilmiş, invertör için ise Kaco New Energy markasının invertörleri seçilmiştir. Santraller şebekeye bağlı olarak tasarlanmıştır. Güneş enerjisi santrallerinin tasarımı ve analizi için PVsyst programı kullanılmıştır. Santrallerin banka kredisi alınmadan ve banka kredisi alınarak kurulması durumları incelenmiştir. Banka kredisi kullanılmadan yapılan analizlerin sonucunda en kısa geri ödeme süresi 4,5 yıl ile Divriği ve Yıldızeli ilçelerinde polikristal paneller ile kurulan santrallerde gözlenmiştir. En uzun geri ödeme süresi ise 6,3 yıl ile Zara ilçesinde monokristal paneller ile kurulan santralde olmuştur. Merkez ilçe ve Yıldızeli ilçesinde monokristal panellerle kurulan santrallerin en yüksek performans oranına sahip olduğu tespit edilmiştir. En düşük performans oranı Gürün ilçesinde polikristal paneller ile kurulan santralde olmuştur. En düşük birim maliyet $0,04443 \$ / \mathrm{kWh}$ ile Divriği ilçesinde polikristal panellerle kredi alınmadan kurulan santralde olurken en yüksek birim maliyet ise 0,06159 \$/kWh ile Zara ilçesinde monokristal panellerle kredi alınarak kurulan santralde olmaktadır. Yapılan çalışmaların sonucunda yıllık üretilen elektrik enerjisi en fazla Gürün ilçesinde, en az Zara ilçesinde olmaktadır. Yapılan ekonomik analizin sonucunda, en fazla kar monokristal paneller için Divriği ilçesinde, polikristal paneller için Yıldızeli ilçesinde olmaktadır. Bu çalışmadan elde edilen bulguların Sivas ili ve ilçelerinde kurulacak güneş enerjisi santralleri için faydalı olacağı düşünülmektedir.

Anahtar Kelimeler: Yenilenebilir Enerji, Güneş Enerjisi, PVsyst, Fotovoltaik Sistemler.

\section{Design and Analysis of Grid Connected Solar Power Plants in Different Districts of Sivas Province}

\begin{abstract}
Due to the decrease in fossil fuels and causing environmental pollution, the importance of electrical energy production from renewable energy has increased in recent years. Accordingly, the number of wind and solar power plants established in the world and in our country is gradually increasing. Our country has a very productive position in terms of solar energy. Therefore, many studies are carried out in this area. In this study, 10 solar power plants were designed and analyzed using monocrystalline panels with an
\end{abstract}

*Sorumlu Yazar: vsari@cumhuriyet.edu.tr 
installed power of $10 \mathrm{MW}$ and polycrystalline panels with an installed capacity of 9,999 MW in 5 districts of Sivas. The panels used are designed as a fixed inclined system, the panel inclination angle is $35^{\circ}$ and the azimuth angle is $0^{\circ}$. In the design of the monocrystalline system, 34.482 panels of 290 Watt and 148 inverters of $72 \mathrm{~kW}$ were used. The panels are connected in 21 series and 1.642 in parallel. The total area of the modules is $56.440 \mathrm{~m}^{2}$. In the design of the polycrystalline system, 34.480 panels of $290 \mathrm{Watt}$ and 148 inverters of $72 \mathrm{~kW}$ were used. The panels are connected in 20 series and 1.724 in parallel. The total area of the modules is $66.161 \mathrm{~m}^{2}$. Monocrystalline panels of Trina Solar brand and polycrystalline panels of Canadian Solar company were chosen for the system design, and inverters of Kaco New Energy brand were chosen for the inverter. The power plants are designed as connected to the grid. PVsyst program was used for the design and analysis of solar power plants. Establishment of power plants without a bank loan and with a bank loan has been examined. As a result of the analysis made without using bank loans, the shortest repayment period was observed in the power plants established with polycrystalline panels in Divriği and Yildizeli districts with 4,5 years. The longest payback period was 6,3 years in the power plant established with monocrystalline panels in Zara district. It has been determined that the power plants installed with monocrystalline panels in the central district and Yildizeli district have the highest performance rate. The lowest performance rate was in the power plant established with polycrystalline panels in Gürün district. The lowest unit cost is $0,04443 \$ / \mathrm{kWh}$ in the power plant established in Divriği district without a loan with polycrystalline panels, while the highest unit cost is $0,06159 \$ / \mathrm{kWh}$ in the power plant established in Zara district with a loan with monocrystalline panels. As a result of the studies carried out, the annual electricity generated is the highest in Gürün district and at least in Zara district. As a result of the economic analysis, the highest profit is in Divriği district for monocrystalline panels and in Yildizeli district for polycrystalline panels. It is thought that the findings obtained from this study will be useful for the solar power plants to be established in Sivas province and its districts.

Keywords: Renewable Energy, Solar Energy, PVsyst, Photovoltaic Systems.

\section{Giriş}

Enerji, insanların ihtiyaçlarının karşılanması için vazgeçilmezdir. Ayrıca ülkelerin geleceğini, güvenliğini etkileyen ve yönlendiren ana faktörlerden biridir. Küresel alanda yaşanan krizlerin en önemli nedenlerinden biri enerji kaynaklarıdır (Erdoğan, 2020). Günümüzde enerji ihtiyacının büyük bölümü fosil yakıtlardan karşılanmaktadır. Fosil yakıtlar çevreye zarar vermekte ve küresel isınmaya sebep olmaktadır. $\mathrm{Bu}$ yüzden daha yaşanabilir bir gelecek için çevreye zarar vermeyen yenilenebilir enerji kaynaklarının kullanımının artması gerekmektedir. Yenilenebilir enerji, gelecek nesillerin ihtiyaçlarını karşılayabilmeleri için gerekli olan kaynakları tüketmeden, bugünün ihtiyaçlarını karşılayabilen enerji biçimini ifade eder (Türkmen, 2020). Yenilenebilir enerjinin yaygınlaşması için 1992 yılında Brezilya' nın Rio kentinde gerçekleşen Rio Deklarasyonunda (Rio Declaration, 1992) iklim değişikliğinin ana sebebi olarak görülen fosil yakıtların yerini yenilenebilir enerji kaynaklarının alması gerektiği ve ülkelerin bu kaynakların kullanımını artırması gerekliliği vurgulanmıştır. Ayrıca ülkelerin yenilenebilir enerjiyi kullanarak ihtiyaç duydukları enerjileri kendi olanaklarıyla üretmeleri sonucunda enerjide dışa bağımlılı̆̆ı da azalacaktır.

Yenilenebilir enerji kaynaklarının başında gelen güneş enerjisi, dünyamız için sonsuz bir enerji kaynağıdır. Güneşten yeryüzüne gelen enerjinin şiddeti $0-1100 \quad \mathrm{~W} / \mathrm{m}^{2}$ arasında değişmektedir. Güneşten dünyaya gelen güç insanlığın yıllık ticari ihtiyacının 16.000 katından fazla ve dünyadaki elektrik santrallerinin toplam gücünün 61.000 katından fazladır (Erkınay, 2012). Ülkemiz küresel 1şınım miktarı bakımından oldukça elverişli bir konumda bulunmaktadır ve 6,8 saat ortalama günlük güneşlenme süresine sahiptir (T.C. Tarım ve Orman Bakanlığ Meteoroloji Genel Müdürlüğü, Türkiye Günlük Güneşlenme Süreleri, 2020). Şekil 1' de Türkiye' nin aylık ortalama küresel ışınım değerleri gösterilmektedir (T.C. Tarım ve Orman Bakanlığı Meteoroloji Genel Müdürlüğü, Türkiye Global Güneş Radyasyonu Uzun Yıllar Ortalaması, 2020). Şekil 2' de Türkiye' nin aylık ortalama güneşlenme süreleri gösterilmektedir (T.C. Tarım ve Orman Bakanlığı Meteoroloji Genel Müdürlüğü, Aylık
Ortalama Güneşlenme Süresi, 2020). Şekil 3' de Türkiye' nin ortalama günlük toplam güneşlenme süresi dağılımı gösterilmektedir (T.C. Tarım ve Orman Bakanlığı Meteoroloji Genel Müdürlüğü, Türkiye Günlük Güneşlenme Süreleri, 2020). Şekil 4' de Türkiye küresel yatay ışınım haritası gösterilmektedir (Huld, 2020).

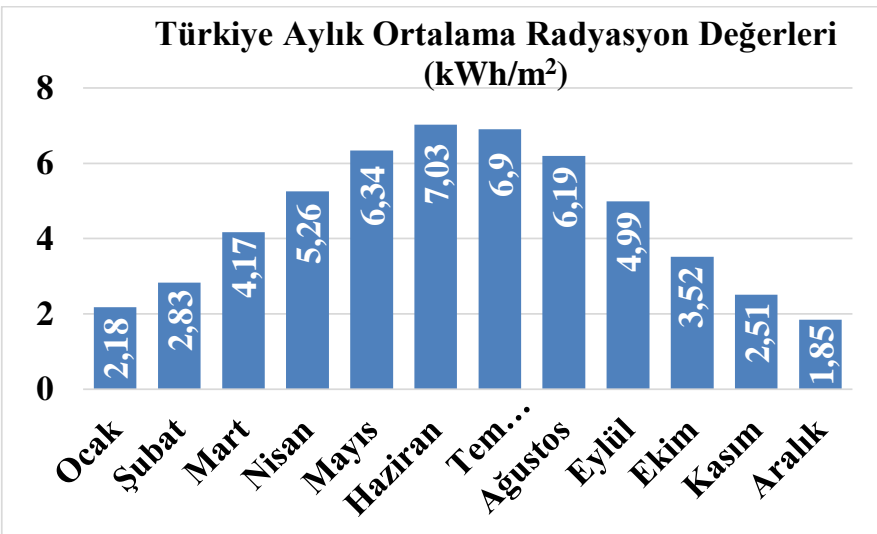

Şekil 1. Türkiye'nin aylık ortalama küresel ışınım değerleri (Fig 1. Turkey's monthly average global radiation values)

Verilerden ve haritalardan da görüldüğü üzere ülkemiz güneş enerjisi bakımından oldukça verimli bir konuma sahiptir. $\mathrm{Bu}$ nedenle bu konuda birçok çalışma yapılmıştır. Çekirdek (2017) yaptığ çalışmada, Konya ve Balıkesir illerinde 0,883 kWh gücünde şebeke bağlantılı sistem tasarlamıştır. Sabit eğik sistemler, tek ve çift eksen sistemler ayrı ayrı incelenmiştir. Sistemlerin incelenmesinde PVsyst programı kullanılmıştır. En fazla enerji çift eksenli sistemlerden elde edilmiştir. İki şehir arasında güneşlenmeye bağlı olarak geri dönüş süreleri aralarında 1 yıl fark ettiği ve Konya ilinde daha erken geri dönüş sağlandığ 


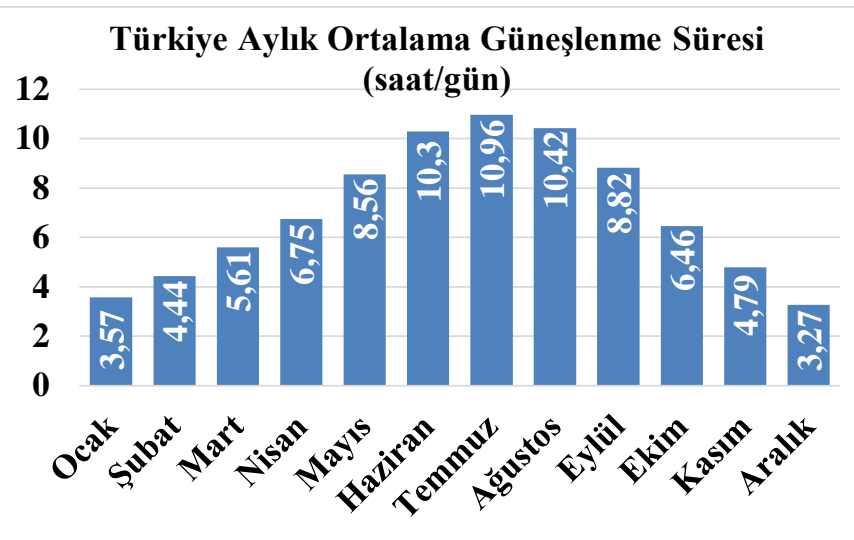

Şekil 2. Türkiye aylık ortalama güneşlenme süreleri (Fig 2. Average monthly sunshine duration in Turkey)

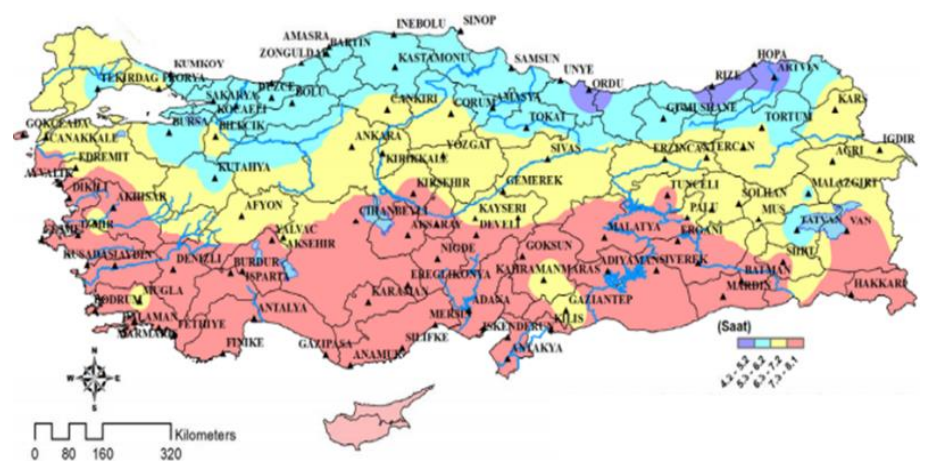

Şekil 3. Türkiye ortalama günlük toplam güneşlenme süresi

dağılımı (Fig 3. Average daily sunshine duration distribution Turkey)

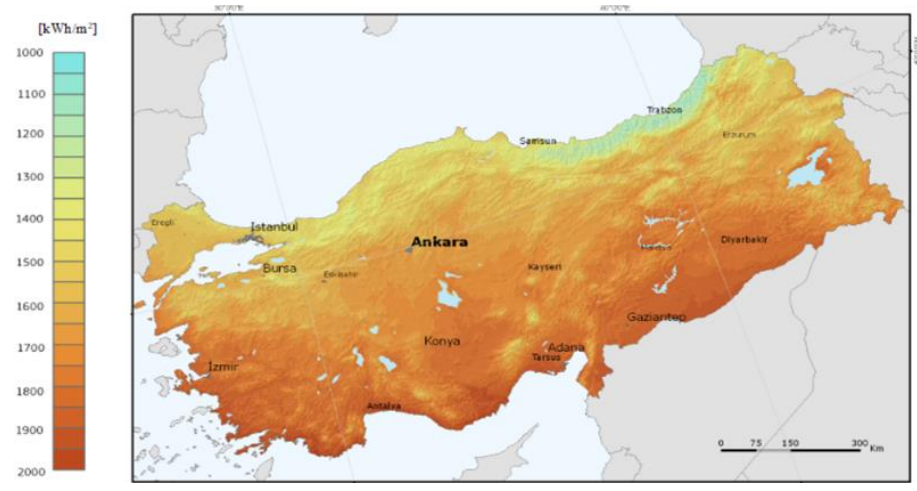

Şekil 4. Türkiye küresel yatay ışınım haritası (Fig 4. Turkey global horizontal irradiation map)

Tekkale (2018) yaptığı çalışmada, ışınım değerleri farklı olan bölgelerde 1.140,48 kW kurulu güce sahip güneş enerjisi santrallerinin yapılabilirlik durumlarını PVsyst programı ile araştırmıştır. GES (Güneş Enerji Santrali)' lerde yatırım belirli bölgelere yapılmakta ve arazi fiyatı buralarda artmaktadır. Yapılan çalışmada en hızlı geri dönüş, ışınım değeri en yüksek olan şehir Şanlıurfa' da olurken, en uzun geri dönüş ise Ankara' da olmuştur. Şehirlerarasındaki geri dönüş süresi farkının 1 yıl kadar olduğu tespit edilmiştir.

Koçak (2018) yaptı̆̆ı çalışmada, Büyükçekmece ilçesinde 4 farklı panel ve 2 farklı invertör kombinasyonlarından oluşan 5,5$6 \mathrm{MW}$ arası değişen kurulu güce sahip güneş enerji santrallerinin analizleri $\mathrm{FV} * \mathrm{SOL}$ programı yardımıyla gerçekleştirmiştir. Yapılan güneş enerji santralinin ekonomik analizi için iç karlılık oranı ve geri ödeme süresi hesabı yapılmıştır.
Kahraman (2018) yaptığı çalışmada, Kütahya ili için 1 MW' lık güneş enerjisi santrali ve rüzgâr enerjisi santralinin fizibilite çalışmasını gerçekleştirmiştir. Çalışma gerçekleştirilirken RETScreen ve Homer programları kullanmıştır. Çalışmada \% 50 öz sermaye ve \% 100 öz sermaye olmak üzere iki farklı durum incelenmiştir. Güneş enerji santrali için ilk senaryoda yatırım maliyetlerinin yarısı olarak kredi kullanımında 11 yıl geri ödeme süresi ve 56.467 \$ net değer ve iç karlılık oranı \% 11,9 olarak hesaplanmıştır. Yapılan ikinci senaryoda ise maliyetlerin tamamı sermayeden karşılandığı durumda geri ödeme süresi 11 yıl, net değer 13.624 \$ ve iç karlılık oranı ise \% 9,8 olarak hesaplanmaktadır. Yapılan bu çalışmada iki senaryonun da uygulanabilir olduğu ancak ilk senaryonun daha mantıklı olduğu vurgulanmıştır.

Aldudak (2018) yaptığı çalışmada, kurulu güneş enerjisi santralinden elde edilen sonuçları PVsyst programı hesaplamalarıyla karşılaştırmıştır. Program çıktıları ile güneş enerjisi santral verileri arasındaki tutarlılık vurgulanmıştır. Yatırımcılara fikir vermesi amacıyla, farklı bölgeler için PVsyst programı ile simülasyon çalışması gerçekleştirilmiştir.

Girgin (2011) yaptığı çalışmada, Karaman bölgesinde 5 MW gücünde 36 farklı sistemin enerji üretimi ve ekonomik analizini yapmıştır. Sistemler $32^{\circ}$ panel eğimine sahip sabit eğik sistemler, tek eksen ve çift eksen sistemler olarak gerçekleştirilmiştir. Hesaplamalar PVsyst programı aracılığıyla yapılmıştır. Tek eksen güneş takip sistemlerinde \%24' e kadar bir artı̧̧ ve çift eksen takip sistemlerinde ise $\% 35^{\prime}$ e kadar bir artış gözlemlenmiştir.

Keskin (2012) yaptığ çalışmada, Dünya' da ve Türkiye' de bulunan 7 il için şebekeden bağımsı $5 \mathrm{~kW}$ ' lık sistem modellemesi gerçekleştirmiştir. Modellemeler için PVsyst programı kullanılmıştır. Elde edilen sonuçlarda enlemin üretilen enerjiye etkisi gözlemlenmektedir. En yüksek verim monokristal modüller ile elde edilmiş, amorf silikon teknolojili modüllerde ise en yüksek üretim değerine ulaşılmıştır. Sistem maliyeti monokristal, polikristal ve amorf silikon teknolojili modüllerde 19 ile 24 yıl arasında sistemin sağladığı enerjinin, elektrik toplam maliyetine denk geleceği hesaplanmıştır.

Eyigün (2010) yaptığı çalışmada, Meteonorm meteoroloji verilerini kullanarak, PVsyst programı yardımıyla Türkiye' nin 7 farklı bölgesinde bulunan iller için farklı modül teknolojileri ve farklı evirici konseptleriyle aynı boyuttaki fotovoltaik (FV) santrallerin verimlilik ve üretim maliyetlerini karşılaştırmıştır. İç Anadolu, Güneydoğu Anadolu ve Akdeniz bölgesinde kurulacak FV santrallerin yıllık $\mathrm{kWp} / \mathrm{kWh}$ enerji üretimlerinin en yüksek değerde olduğu, Karadeniz ve Doğu Anadolu bölgelerinde kurulacak $\mathrm{FV}$ santrallerin ise $\mathrm{kWp} / \mathrm{kWh}$ enerji üretim değerlerinin düşük olduğu gözlemlenmiştir.

Akcan vd. (2020) tarafından yapılan çalışmada, PVsyst programı ile Batman merkezde bulunan bir okulun enerji ihtiyacının karşılanması amacıyla çatı tipi FV bir sistem tasarlanmıştır. $\mathrm{Bu}$ sistemin üreteceği enerji miktarı, sistem performansı ve sistemde bulunan elemanların birbirleriyle uyumluluğu üzerine değerlendirmeler yapılmıştır. Gün ışığının olmadığı durumlarda okulun enerji ihtiyacının şebekeden karşılanacağı, yeterli olması durumunda ise üretim fazlasının şebekeye aktarılacağı şekilde tasarlanmıştır. Okulda üretilen y1llık 35,31 MWh enerji şebekeye satılarak okul için gelir elde edilmesi planlanmıştır. FV sistemden elektrik üretiminin Batman ili için iyi bir seçenek olduğu sonucuna varılmıştır. 
Akyazı vd. (2019) yaptıkları çalışmada, şebeke ile entegreli, güneș enerjisi ile şarj edilebilen, akü sistemi üzerinden beslenen akıllı LED'li bir aydınlatma armatürü tasarlamış ve uygulamasını gerçekleştirmişlerdir. Yapılan deneysel çalışmalarda LED'li aydınlatma armatürünün 1şık şiddeti yaya veya araç trafiğine bağlı olarak değişmekte ve sürekli aynı şiddette yanmayarak enerji tasarrufu sağladığı ve kullanılabilir olduğu görülmüştür.

Güner \& Muharremoğlu (2020) yaptıkları çalışmada, Adnan Menderes Havalimanının otoparkına kurulabilecek bir FV üretim sisteminin tasarımı ve ürettiği enerji ile otoparkın enerji ihtiyacını karşılayıp karşılamadığının analizinin yapmışlardır. FV sistemin gücü $534 \mathrm{~kW}$ olarak hesaplanmıştır. Toplamda $2.770 \mathrm{~m}^{2}$ alanı kaplamaktadır. 1.617 adet $330 \mathrm{~W}$ gücünde LG330N1C-A5 marka monokristal güneş paneli kullanılmıştır. Paneller 21 seri modül ve 77 paralel diziden oluşmaktadır. Otoparkın bir aylık saatlik tüketim bilgisi kullanılarak otoparkın ortalama günlük yük eğrisi elde edilmiştir. $\mathrm{Bu}$ iki bilgi karşılaştırılarak havalimanının enerji analizi yapılmıştır. $\mathrm{Bu}$ çalışmanın sonucunda adı geçen havalimanı otoparkına sistemin projelendirmesi hazırlanmıştır. $\mathrm{Bu}$ çalı̧̧mada teorik ile uygulamanın birleştirilmesi de hedeflenmiştir.

Dandıl \& Gürgen (2019) tarafindan yapılan çalışmada, geriye yayılım algoritmasının yanında iki farklı sezgisel yöntem kullanılarak eğitilen bir yapay sinir ağı (YSA) modeli kullanılmıştır. $\mathrm{Bu}$ YSA modeli ile farklı eğim açılarında $\left(10^{\circ}, 20^{\circ}, 30^{\circ}, 40^{\circ}, 50^{\circ}, 60^{\circ}\right)$ yerleştirilmiş $\mathrm{FV}$ panel güç çıkışlarının, akım ve gerilim değerlerine bağlı olarak aylık olarak tahmin edilmesine yönelik hibrit bir yöntem geliştirilmiştir. Yöntemin elde edilen sonuçlar üzerindeki etkinliği ölçüm yapılan gerçek ve tahmin edilen değerler arasındaki ortalama yüzdelik hatanın analizi ile doğrulanmıştır. Çalışmada Bilecik Şeyh Edebali Üniversitesi yerleşkesi içerisine kurulmuş FV panel test düzeneğinden elde edilen veriler kullanılmıştır. Düzeneğe yerleştirilen her bir FV panel Perlight marka ve PLM$100 \mathrm{P} / 12$ model olup polikristal yapıya sahiptir.

Türkdoğan vd. (2020) yaptıkları çalışmada, 40 haneli bir topluluğun şebekeden bağımsız elektrik ve termal yük ihtiyacını karşılamak için çeşitli hibrit enerji sistemlerinin teknik ve ekonomik analizlerini yapmıştır. Ortalama $320 \mathrm{kWh} /$ gün elektrik ve $142,47 \mathrm{kWh} /$ gün termal yük ihtiyaçlarının karşılanması ve bu amaç için HOMER (Hybrid Optimization Model for Electric Renewable) programı kullanılarak kurulacak enerji sistemlerinin üreteceği enerjinin birim fiyatı tespit edilmiştir. Manisa'nın Gördes bölgesi Türkiye'nin ortalama güneş radyasyonu değerlerine yakın parametrelere sahip olduğundan seçilmiştir. Simülasyon sonuçlarına göre hibrit sistemde bataryaların etkili bir şekilde kullanılması gerektiği görülmüștür. Yapılan araştırmalar sonucunda seçilen sistemin kurulum maliyeti 215.958 \$, operasyon maliyeti 18.029 \$ ve tüm projenin net bugün ki maliyeti 598.958 olduğu hesaplanmıştır. Birim enerji maliyetinin 0,164 \$ seviyelerine indiği görülmüsşür.

Akboy (2019) tarafindan yapılan çalışmada, $1 \mathrm{~kW}$ gücü ve $100 \mathrm{kHz}$ anahtarlama frekansına sahip şebekeye bağlı bir FV sistem kurularak, PSIM programı ile simülasyonu gerçekleştirilmiştir. Sistemde $250 \quad \mathrm{~W}-1.000 \quad \mathrm{~W} / \mathrm{m}^{2} \quad$ 1şıııım özelliklerine sahip 4 eş panel seri bağlanmıştır. Farklı ışınım ve güç değerleri altında sistem çalıştırılarak şebeke etkileri incelenmiştir. Elde edilen sonuçlarda farklı koşullar altında hedeflenen sistemin, ilgili kontrol algoritmalarına bağlı olarak hızlı dinamik cevap verme süresine sahip olduğu ve şebeke tarafinda her zaman yüksek güç faktörü elde edildiği gözlemlenmiştir.

Yağlı \& Koç (2020) yaptıkları çalışmada, Gaziantep bölgesinde kurulacak güneş enerjisi üretim tesislerinde panellerin optimum açıları belirlenmeye çalışılmıştır. Realiteye en yakın sonuç verdiğinden PVsyst programı seçilmiştir. Programa azimut açı değeri girilmiş, elde edilen transpozisyon faktörü değerleriyle birlikte panellerin eğim açılarına göre ürettikleri enerji miktarları değerlendirilmiştir. Gaziantep bölgesi için en uygun açının $30^{\circ}$ olduğu tespit edilmiştir.

Sarı \& Özyiğit (2020) yaptıkları çalışmada, Sivas Cumhuriyet Üniversitesi yerleşkesinde PVsyst programını kullanarak polikristal ve monokristal panellerden oluşan 0,999 MW gücünde iki ayrı güneş enerji üretim santrali tasarlamışlardır. Bu iki santral kurulum maliyeti, enerji üretimi ve karlılık yönünden incelenmiştir. Monokristal panellerin kurulum masrafinın polikristal panellerden daha fazla olduğu tespit edilmiştir. Buna karşın monokristal modül kullanılması durumunda monokristal modül veriminin daha yüksek olması sebebiyle sistem ömrü sonunda getirdiği kazancın daha fazla olacağ 1 tespit edilmiştir. Polikristal paneller kullanılarak oluşturulan sistemlerde ise ilk kurulum maliyetlerinin monokristal panellere göre daha düşük olması sebebiyle daha erken dönüşler gözlemlendiği tespit edilmiştir.

$\mathrm{Bu}$ çalışmada ise Sivas ilinin beş ayrı ilçesinde kurulacak 10 MW gücündeki toplam 10 adet güneş enerji santralinin tasarımı ve analizi yapılmıştır. Böylelikle Sivas ilinin beş farklı ilçesindeki bölgesel ve dolayısıyla iklimsel farklılıkların güneş enerji üretim santrallerinin kurulum, işletme ve ekonomisine etkileri de araştırılmıştır. Bu çalışmada incelenen santral $10 \mathrm{MW}$ gücündedir. Sarı \& Özyiğit (2020)' nin yaptıkları çalışmada ise santral 0,999 MW gücündedir. Dolayısıyla aynı bölgede farklı güçteki santrallerin karşılaştırması da yapılabilir.

Ülkemizin dışındaki diğer ülkelerde de güneş enerjisinden elektrik üretimi konusunda birçok araştırma yapılmıştır. Barua vd. (2017) yaptıkları çalışmada, Hindistan'da bulunan Pondicherry Üniversitesi'nin çatısına FV sistemin kurulumunu ve analizini PVsyst programını kullanarak yapmıştır. Simülasyon sonucunda yıllık 590 MWh enerji üretileceği tespit edilmiştir. Bu değerin Pondicherry Üniversitesi'ndeki toplam ylllık enerji tüketiminin yaklaşı \% 11'i olduğu belirtilmiştir.

Ramoliya (2015) yaptığı çalışmada, PVsyst programını kullanarak şebekeye bağlı 1 MW gücündeki güneş enerji santralinin performansını incelemiş ve kayıp güçlerini hesaplamıştır. Modül kalite kaybı yıllık $802,14 \mathrm{kWh}$, modül uyumsuzluğu kaybı yıllık $32.055 \mathrm{kWh}$, omik kablolama kaybı yıllık $15.476 \mathrm{kWh}$ ve toplam inverter kayb1 y1llık $33.326 \mathrm{kWh}$ olarak bulunmuştur. Gujarat'ın Shapur Köyü'nde oluşturulan santralin yıllık 1.416.980 KWh enerji ürettiği hesaplanmıştır. Sistemin veriminin yıllık ortalama 0,764 olduğu tespit edilmiştir.

Kumar vd. (2017) yaptıkları çalışmada, şebekeye bağlı 100 $\mathrm{KW}$ gücünde bir $\mathrm{FV}$ sistemin PVsyst programı ile simülasyonunu yapmışlar ve performansını analiz etmişlerdir. Ayrıca iklimsel veriler Meteonorm programından elde edilmiştir. Kurulan sistem, her biri $310 \mathrm{~W}$ gücündeki 323 adet FV modülden oluşmaktadır. Tüm FV modüller 17 dizi halinde düzenlenmiş ve her bir dizi seri olarak 19 modülden oluşmaktadır. İncelemelerin sonucunda sistemin şebekeye yıllık 161,6 MWh enerji vereceği tespit edilmiştir. Sistemin veriminin $\% 80$ olduğu hesaplanmıştır. 
Cavalcante vd. (2019) tarafından yapılan çalışmada, Brezilya'nın Mogi Mirim şehrinde $3 \mathrm{MW}$ gücündeki güneş enerji santralinin analizini PVsyst programı ile analiz etmişlerdir. Santralde 330W gücünde toplam 9.900 adet Canadian Solar marka polikristal modül kullanılmıştır. Santralin şebekeye y1ll1k 4.560 MWh enerji vereceğini ve sistemin veriminin \% 76 olduğunu hesaplamışlardır. En yüksek enerjinin Kasım ayında, en düşük enerjinin de Haziran ayında üretileceğini tespit etmişlerdir.

Saxena \& Gidwani (2018) yaptıkları çalışmada, $100 \mathrm{~kW}$ gücünde şebeke bağlantılı Hindistan' in Rajasthan eyaletinin Kota şehrinde çatıya kurulması düşünülen bir güneş enerji santralini PVsyst programı ile analiz etmişlerdir. Verimi \% 11,27 olan FV modüller ve verimi \% 97,6 olan inverter kullanılarak oluşturulan sistemin yıllık ürettiği enerji $167,8 \mathrm{MWh}$ olarak bulunmuştur. Analiz edilen FV sistemin verimi \% 75,7 dir. Aylık olarak üretilen en yüksek enerji $16.437 \mathrm{kWh}$ ile Mart ayında, $11.453 \mathrm{kWh}$ ile Ağustos ayında olmaktadır.

Tallab \& Malek (2015) yaptıkları çalışmada, PVsyst programını kullanarak Cezayir' de $1 \mathrm{MW}$ gücünde bir FV sistem tasarımı ve analiz yapmışlardır. Gerçekleştirilen güneş enerjisi santrali ile yıllık 1.805 MWh elektrik enerjisi üretimi yapıldığ ve sistemin veriminin \% 77,8 olduğu hesaplanmıştır. Panellerin açısı mevsimsel olarak değiştirildiğinde yaz-kış sabit açılı panellere göre \% 5 daha fazla elektrik üretimi yapıldığı tespit edilmiştir.

Satish vd. (2020) yaptıkları çalışmada, Dubai’ de $200 \mathrm{~kW}$ gücünde şebeke bağlantılı monokristal panellerden oluşan FV sistemin kurulumu ve incelemesini PVsyst programı ile yapmışlardır. Tasarlanan sistem 22 adet seri ve 32 adet paralel bağlanmış toplam 704 adet panelden oluşmaktadır. Sunmodule markalı $285 \mathrm{~W}$ gücündeki monokristal paneller $25^{\circ}$ lik açı ile yerleştirilmiştir. Sistemin yıllık 352,6 MWh enerji ürettiği belirtilmiştir.

Saraswat (2016) yaptığı çalışmada, aynı yük ve hava koşullarında farklı üreticilerin güneş panellerinin karşılaştırmalı performans analizini yapmışlardır. Farklı güneş panellerinin kayıplar ve verimlilik açısından karşılaştırmalı analizi tablo şeklinde sunulmuştur. $\mathrm{Bu}$ çalışmada PVsyst programı kullanılmıştır.

Rout \& Kulkarni (2020) yaptıkları çalışmada, 2 kW gücünde çatıya kurulması düşünülen şebekeye bağlı bir FV sistemi PVsyst programı ile oluşturarak analiz etmişlerdir. Panel eğim açısı $20,3^{\circ}$ dir. Kullanıcı yüklerinin $3.244,8 \mathrm{kWh}$ olduğu, sistemin 2.962,4 kWh enerji ürettiği ve aradaki $33,23 \mathrm{kWh}$ 'lik enerji farkının şebekeden karşılanacağı tespit edilmiştir.

\section{Materyal ve Metot}

Bu çalışmada PVsyst programı kullanılarak Sivas ilinin beş farklı ilçesinde kurulacak santrallerin modellemesi ve hesaplamaları yapılmıştır. FV sistemler için PVsyst programı ayrıntılı çalışma, boyutlandırma, saatlik simülasyon yapabilmekte ve içerdiği birçok özellikten dolayı gerçek değerlere oldukça yakın sonuçlar verebilmektedir. Ayrıca programın hesaplama sonuçlarına finans kuruluşları kredi vermektedir (Sarı \& Özyiğit, 2020). Şekil 5' de PVsyst program ekranı görülmektedir.

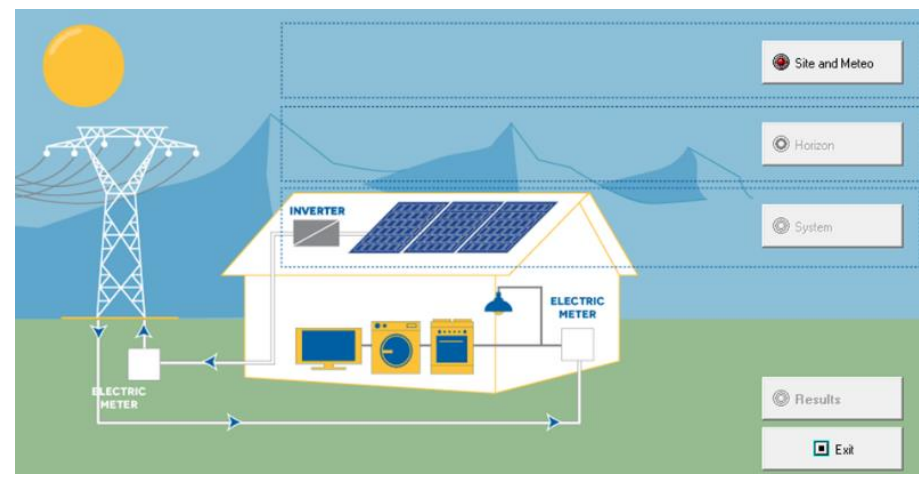

Şekil 5. PVsyst program ekranı (Fig 5. PVsyst program screen)

\section{1. İklimsel Veriler}

Tablo 1' de Sivas ilinin iklimsel verileri görülmektedir (T.C. Tarım ve Orman Bakanlığı Meteoroloji Genel Müdürlüğü, Resmi İstatistikler). Şekil 6' da Sivas ilinin aylara göre küresel ışınım değerleri, Şekil 7' de ise Sivas ilinin ilçelere göre küresel 1şınım değerleri görülmektedir (T.C. Enerji ve Tabii Kaynaklar Bakanlığı, Enerji İşleri Genel Müdürlüğü, Güneş Enerjisi Potansiyel Atlas1).

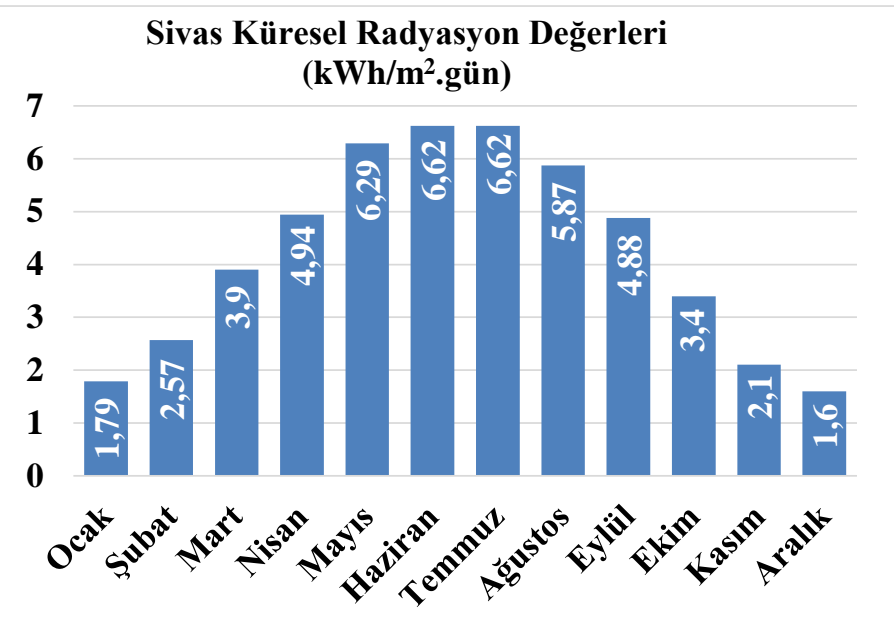

Şekil 6. Sivas ilinin aylara göre küresel ışınım değerleri (Fig 6. Global radiation values of Sivas province according to months)

\subsection{Yer Seçimi}

Proje kurulumu için yer seçimi yapılırken arazinin eğimi, toprak türü, güney yönüne cephesi, tarım arazisi olmaması ve ulaşım durumu gibi özellikler göz önünde bulundurulmuştur. Santraller için 180 dönümlük bir arazi gerekmektedir. Seçilen araziler sanayi bölgelerine yakın olarak seçilmiştir. Proje alanları belirlenirken, ulaşım altyapısının olması, arazilerin eğimi, toprak türünün proje inşasına uygun olması, arazilerin çevresinde gölge yaratacak yapı veya bitki örtüsü olmaması ve proje alanlarının enerji nakil hattına yakın olması gibi kriterler göz önüne alınmıştır. 


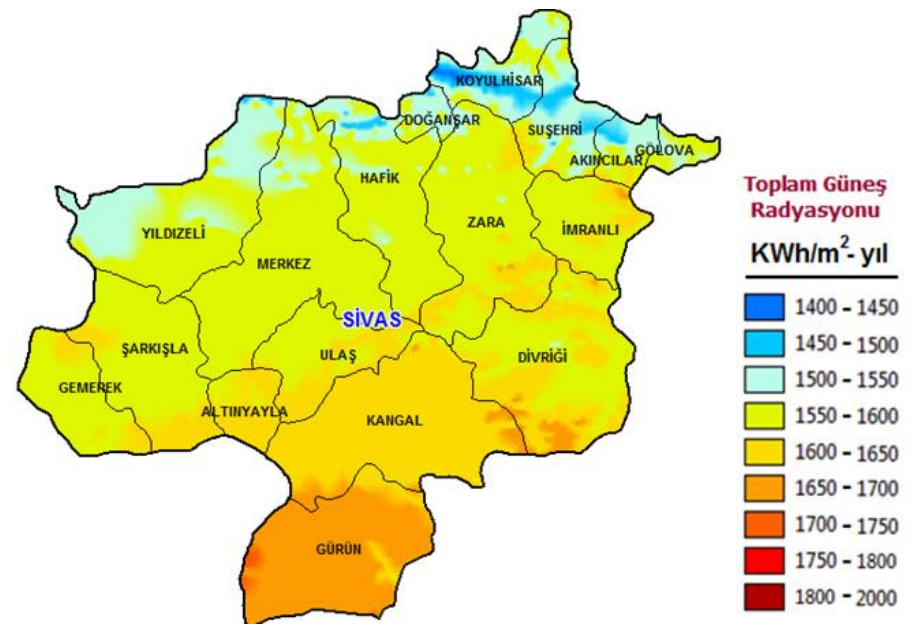

\subsection{Tasarım}

Güneş enerjisi teknolojileri yöntem, malzeme ve teknolojik düzey açısından çok çeşitlilik göstermekle birlikte iki ana gruba ayrilabilir. Bunlar FV güneş teknolojileri ve 1sıl güneş teknolojileridir. FV hücreler, üzerlerine gelen güneş ışığını doğrudan elektrik enerjisine dönüştüren yarıiletken maddelerdir. Güneş enerjisi, güneş hücresinin yapısına bağlı olarak \% 5 ile \% 30 arasında bir verimle elektrik enerjisine çevrilebilir. Güç çıkışını artırmak amacıyla çok sayıda güneş hücresi birbirine paralel ya da seri bağlanır, bu yapıya güneş hücresi modülü ya da FV modül adı verilir. Güç talebine bağlı olarak modüller birbirlerine seri ya da paralel bağlanarak bir kaç Watt' tan Mega Watt' lara kadar sistemler oluşturulabilir (T.C. Enerji ve Tabii Kaynaklar Bakanlığı, Enerji İşleri Genel Müdürlüğü. Güneş Enerjisi ve Teknolojileri).

Şekil 7. Sivas ilinin ilçelere göre küresel ışınım değerleri (Fig 7. Global irradiance values of Sivas province according to districts)

Tablo 1. Sivas ili iklimsel verileri (Table 1. Climatic data of Sivas province)

\begin{tabular}{ccccccc}
\hline Sivas & $\begin{array}{c}\text { Ortalama } \\
\text { Sıcaklık } \\
\left({ }^{\circ} \mathbf{C}\right)\end{array}$ & $\begin{array}{c}\text { Ortalama En } \\
\text { Yüksek } \\
\text { Sıcaklık }\left({ }^{\circ} \mathbf{C}\right)\end{array}$ & $\begin{array}{c}\text { Ortalama } \\
\text { En Düşük } \\
\text { Sıcaklık }\left({ }^{\circ} \mathbf{C}\right)\end{array}$ & $\begin{array}{c}\text { Ortalama } \\
\text { Güneşlenme } \\
\text { Süresi (saat) }\end{array}$ & $\begin{array}{c}\text { Ortalama } \\
\text { Yağışı Gün } \\
\text { Sayısı }\end{array}$ & $\begin{array}{c}\text { Aylık Toplam } \\
\text { Yağış Miktarı } \\
\text { Ortalaması (mm) }\end{array}$ \\
\hline Ocak & $-3,4$ & 0,7 & $-7,3$ & 2,5 & 13 & 43,1 \\
Şubat & $-2,1$ & 2,5 & $-6,3$ & 3,5 & 12,2 & 39,1 \\
Mart & 2,6 & 7,9 & $-2,1$ & 4,8 & 13,3 & 44,9 \\
Nisan & 8,8 & 15 & 3 & 6,3 & 13,4 & 57 \\
Mayıs & 13,4 & 20 & 6,9 & 8 & 14 & 61,1 \\
Haziran & 16,9 & 23,9 & 9,5 & 10,5 & 8,6 & 33,9 \\
Temmuz & 19,9 & 27,7 & 11,6 & 11,9 & 2,4 & 6,7 \\
A ğustos & 20,1 & 28,5 & 11,7 & 11,4 & 2 & 17,8 \\
Eylül & 16,1 & 24,5 & 8 & 9,4 & 4,2 & 33,7 \\
Ekim & 10,8 & 18,4 & 4,1 & 6,4 & 7,8 & 40,4 \\
Kasım & 4,7 & 10,7 & $-0,2$ & 4,2 & 9,3 & 44,8 \\
Aralık & $-0,7$ & 3,5 & $-4,4$ & 2,4 & 12,2 & 432 \\
\hline Yillık & 8,9 & 15,3 & 2,9 & 81,3 & 112,4 & \\
\hline
\end{tabular}

FV hücrelerde yarı-iletken malzeme olarak kristal silikonun (silisyum) kullanıldığ1 sistemlere kristal silikon teknolojisi denilmektedir. Silisyum, oksijenden sonra yer kabuğunda en çok bulunan elementtir. Doğada saf şekilde bulunmayan silisyumun hücre yapımına hazır hale gelmesi için yüksek sicaklık gerektiren işlemler sonucunda silikondioksit bileşiğinden ayrılması gerekmektedir. Üretim sürecindeki farklılıklardan dolay1 kristal silikon FV hücrelerin; monokristal silikon, polikristal silikon ve ribbon silikon hücre olmak üzere üç çeşidi bulunmaktadır. Monokristal silikon FV teknolojilerin dezavantajlarının en başında silisyumun yüksek derecede saflaştırılması işleminin fazla enerji gerektirmesi, karmaşık ve uzun bir süreçte gerçekleştirilmesi ve maliyetli olması gelmektedir. Elektriksel özellikleri açısından monokristal FV hücrelerle hemen hemen aynı olan polikristal silikon FV hücreler monokristal hücreye göre daha az enerji gerektiren bir süreçte üretilmektedir. $\mathrm{Bu}$ nedenle üretim maliyeti daha düşüktür. Ancak, polikristal hücrenin verimliliği monokristal hücrenin verimliliğinden daha düşüktür (Cebeci, 2017).

Bu çalışmada, kullanılacak paneller sabit eğik sistem olarak tasarlanmış, panel eğim açısı $35^{\circ}$ ve azimuth açısı $0^{\circ}$ olarak konumlandırılmıştır. Monokristal sistem tasarımında 290 Watt' lik 34.482 adet panel ve $72 \mathrm{~kW}$ ' lik 148 adet invertör e-ISSN: 2148-2683 kullanılmıştır. Paneller 21 adet seri ve 1.642 adet paralel olacak şekilde bağlanmıştır. Modüllerin toplam alanı $56.440 \mathrm{~m}^{2}$ dir. Polikristal sistem tasarımında 290 Watt' lık 34.480 adet panel ve 72 kW' lık 148 adet invertör kullanılmıştır. Paneller 20 adet seri ve 1.724 adet paralel olacak şekilde bağlanmıştır. Modüllerin toplam alanı $66.161 \mathrm{~m}^{2}$ dir.

Sistem tasarımı için yaygın olarak kullanılan Trina Solar markasının monokristal panelleri ve Canadian Solar firmasının polikristal panelleri seçilmiş, invertör için ise yaygın kullanılan Kaco New Energy markası seçilmiştir. Tablo 2' de kullanılacak FV panel ve invertör marka ve modelleri verilmiştir. Santraller şebekeye bağlı olarak tasarlanmıştır. Şekil 8' de şebekeye bağlı sistemin genel yapısı görülmektedir (Start Solar, 2020).

Tablo 2. Kullanılacak fotovoltaik panel ve Invertör (Table 2. Photovoltaic panel and inverter to be used)

\begin{tabular}{ccc}
\hline Ürün & Üretici & Model \\
\hline Monokristal & Trina Solar Co. & TSM-290DD05A.08(II) \\
Polikristal & Canadian Solar Inc. & CS6X-290P \\
Invertör & Kaco New Energy & Powador 72.0 TL3 Park \\
& & XL \\
\hline
\end{tabular}




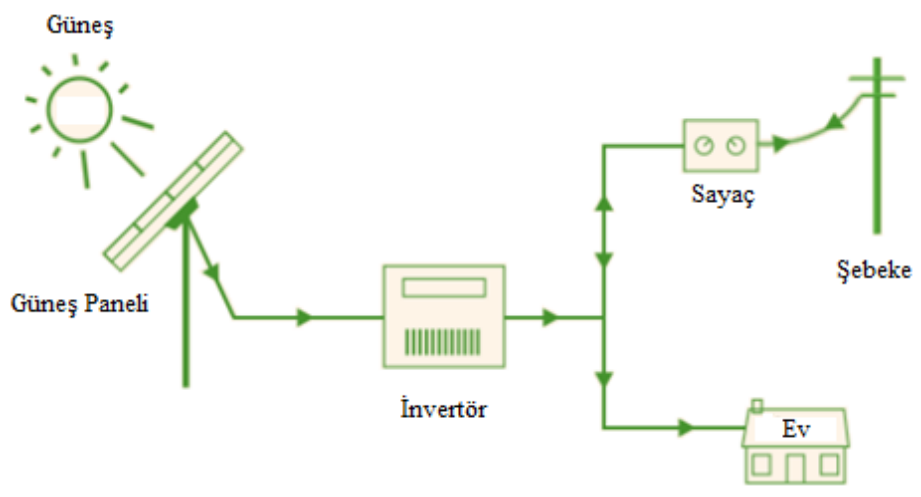

Şekil 8. Şebeke bağlantılı sistem genel yapısı (Fig 8. Gridconnected system general structure)

\subsection{Ekonomik Analiz}

Santrallerin banka kredisi alınmadan \% 100 özsermaye ile ve 8 yıllık geri ödemeli yıllık \% 8,5 faizle banka kredisi alınarak kurulması durumları incelenmiştir. Arazi birim fiyatları $\mathrm{m}^{2}$ olarak belediyenin internet sitesinden (Sivas Belediyesi, 2020) alınmıştır. Tablo 3' de arazilerin toplam fiyatları görülmektedir. Tablo 4' de santrallerin kurulumundaki maliyetler verilmiştir.

Tablo 3. Arazi Fiyatlarl (Table 3. Land Prices)

\begin{tabular}{ccccc}
\hline Merkez & Divriği & Gürün & Yıldızeli & Zara \\
\hline $1.421 .362 \$$ & $174.693 \$$ & $1.778 .688 \$$ & $241.394 \$$ & $2.540 .982 \$$ \\
\hline
\end{tabular}

Tablo 4. Maliyet Tablosu (Table 4. Cost table)

\begin{tabular}{|l|c|}
\hline FV Modül Monokristal & 2.899 .937 \$ \\
\hline FV Modül Polikristal & 2.599 .792 \$ \\
\hline İnverter & 932.400 \$ \\
\hline Geliştirme (Proje ve saha hazırlık) & 186.000 \$ \\
\hline Personel Binası & 20.610 \$ \\
\hline Personel Giderleri & 63.100 \$/y1ll1k \\
\hline Kablolamalar DC-AC & 650.000 \$ \\
\hline Konstrüksiyon & 850.000 \$ \\
\hline Trafo,beton köşk vs. & 410.000 \$ \\
\hline Bakım-Onarım-Temizleme-Sigorta & 126.000 \$y1ll1k \\
\hline İscilik+Nakliye & 660.000 \$ \\
\hline $\begin{array}{l}\text { Diğer (Arazi düzenlemesi, merkezi } \\
\text { izleme odasl, mühendislik, scada } \\
\text { sistemleri, koruma ekipmanlarl vs.) }\end{array}$ & 930.000 \$ \\
\hline
\end{tabular}

\section{Araştırma Sonuçları ve Tartışma}

$\mathrm{Bu}$ çalışmada, Sivas ilinin beş ilçesinde ilk olarak monokristal paneller kullanılarak 10 MW, ikinci olarak polikristal paneller kullanılarak 9,999 MW kurulu güce sahip güneş enerjisi santrali tasarımı gerçekleştirilmiş ve sonuçlar maliyet ve üretim açısından analiz edilmiştir.

Sivas ili Merkez ilçesinde kurulu gücü $10 \mathrm{MW}$ olan monokristal paneller kullanılarak ilk tasarım gerçekleştirilmiştir. Santralin kurulacağı arazinin küresel radyasyon miktarı yıllık $1.573 \mathrm{kWh} / \mathrm{m}^{2}$, dir. Standart Test Koşullarında (STK) verimi $\% 17,72$ (Solar Design Tool, Trina Solar, 2020) olan panellerin dizi nominal enerjisi 17.522 MWh olarak gerçekleşmektedir. Kayıplar çıkarıldığında sistem şebekeye yıllık 15.670 MWh enerji vermektedir. Şekil 9' da merkez ilçede monokristal panellerle oluşturulan santralin enerji kayıp diyagramı verilmiştir. Merkez ilçede yapılan diğer analiz ise kurulu gücü
9,999 MW olan polikristal paneller ile gerçekleştirilmiştir. Kurulum yapılacak arazinin küresel radyasyon miktarı 1.573 $\mathrm{kWh} / \mathrm{m}^{2}$, dir. STK' da verimi \%15,11 (Solar Design Tool, Canadian Solar, 2020) olan panellerin dizi nominal enerjisi 17.515 MWh olarak gerçekleşmektedir. Kayıplar çıkarıldı ğında sistem şebekeye yıllık 15.507 MWh enerji vermektedir. Şekil 10' da merkez ilçede polikristal panellerle oluşturulan santralin enerji kayıp diyagramı görülmektedir.

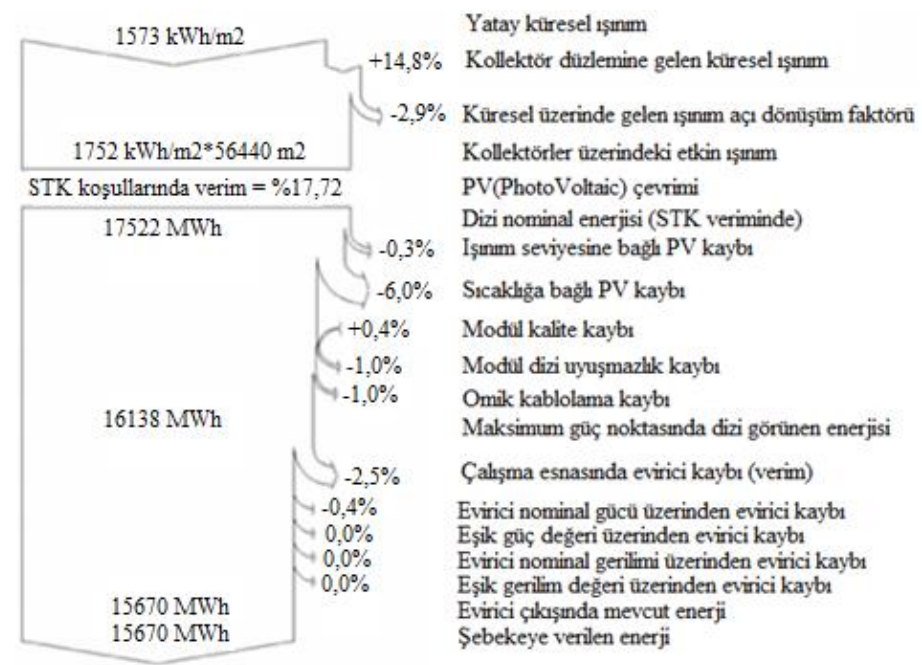

Şekil 9. Merkez ilçede monokristal panellerle oluşturulan santralin enerji kayı diyagramı (Fig 9. Energy loss diagram of the power plant built with monocrystalline panels in the central district)

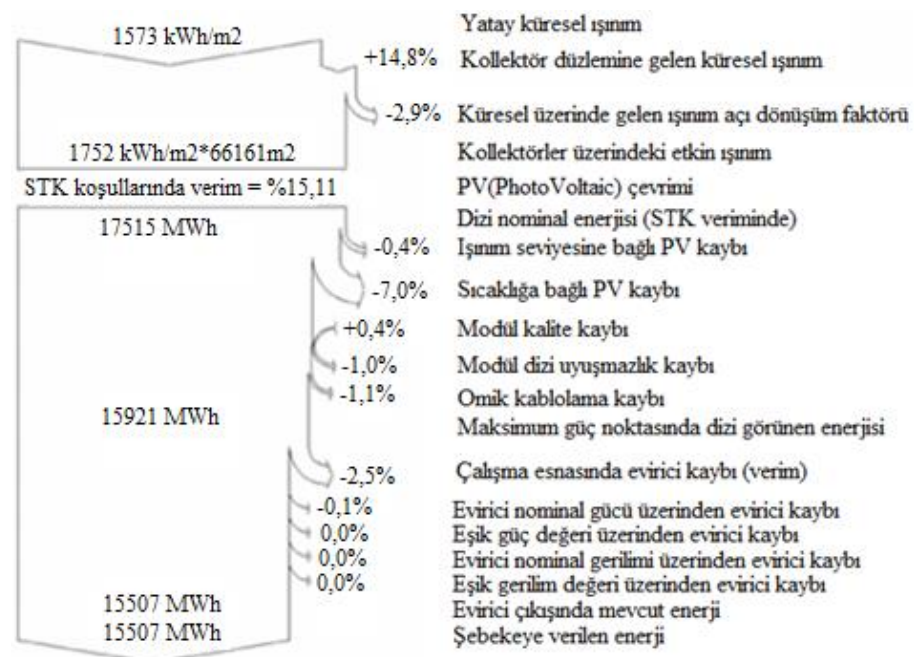

Şekil 10. Merkez ilçede polikristal panellerle oluşturulan santralin enerji kayı diyagramı (Fig 10. Energy loss diagram of

the power plant created with polycrystalline panels in the central district)

Divriği ilçesinde ilk olarak monokristal panel kullanılarak 10 MW kurulu güce sahip güneş enerjisi santralinin kurulum çalışması gerçekleştirilmiştir. Kurulum yapılacak arazinin küresel radyasyon miktarı yıllık $1.569 \mathrm{kWh} / \mathrm{m}^{2}$, dir. Panellerin dizi nominal enerjisi 17.542 MWh olarak gerçekleşmektedir. Kayıplar çıkarıldığında sistem şebekeye yıllık 15.550 MWh enerji vermektedir. Şekil 11' de Divriği ilçesinde monokristal panellerle oluşturulan santralin enerji kayıp diyagramı görülmektedir. Divriği ilçesindeki diğer çalışmada polikristal panel kullanılarak 9,999 MW kurulu güce sahip güneş enerjisi santralinin ekonomik fizibilite çalışması gerçekleştirilmiştir. Panellerin dizi nominal enerjisi 17.535 MWh olarak 
gerçekleşmektedir. Kayıplar çıkarıldı̆̆ında sistem şebekeye yıllık 15.404 MWh enerji vermektedir. Şekil 12' de Divriği ilçesinde polikristal panellerle oluşturulan santralin enerji kayıp diyagramı görülmektedir.

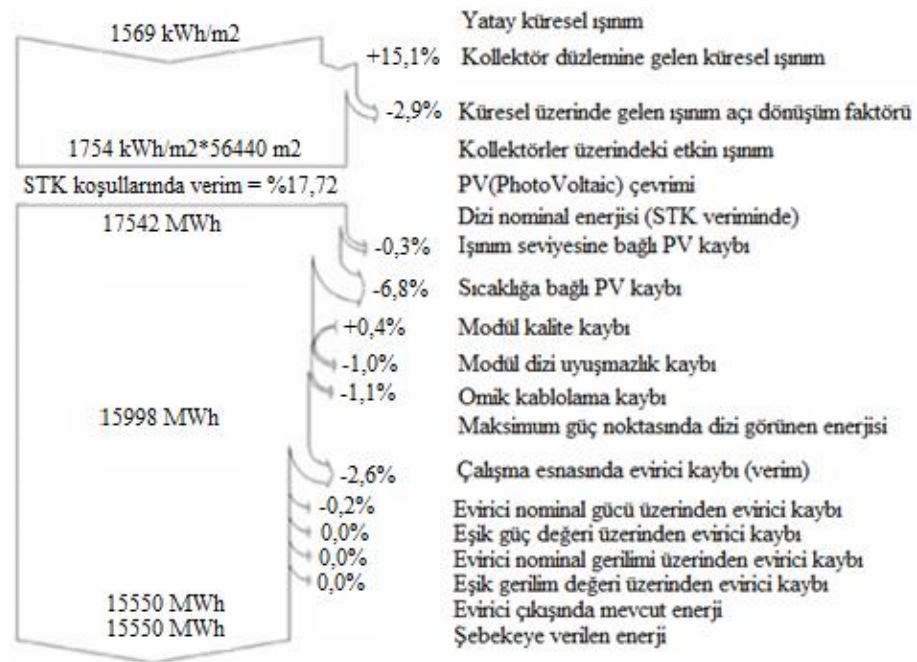

Şekil 11. Divriği ilçesinde monokristal panellerle oluşturulan santralin enerji kayı diyagramı (Fig 11. Energy loss diagram of the power plant built with monocrystalline panels in Divriğ $i$ district)

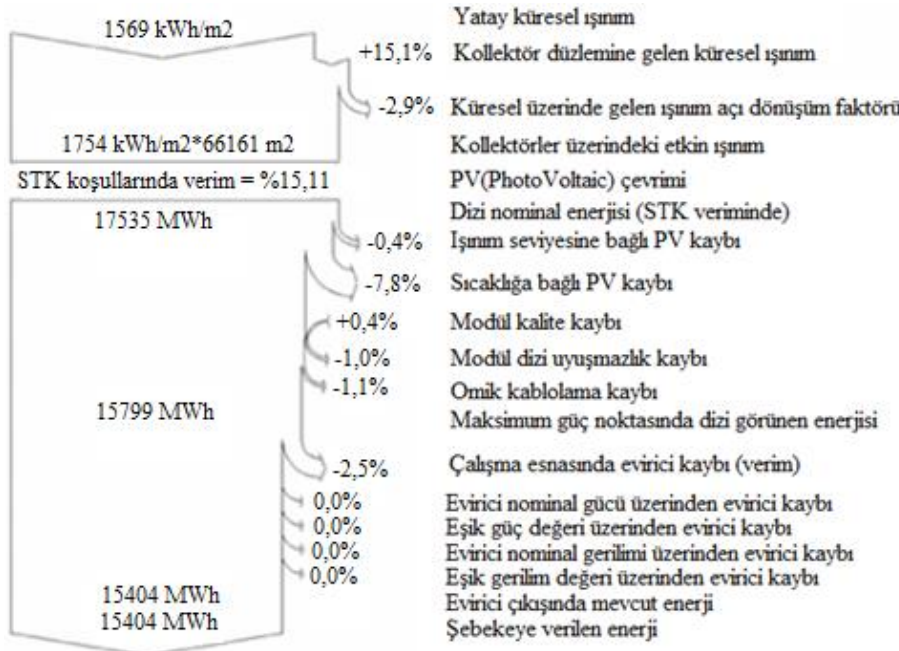

Şekil 12. Divriği ilçesinde polikristal panellerle oluşturulan santralin enerji kayıp diyagramı (Fig 12. Energy loss diagram of the power plant built with polycrystalline panels in Divriğ $i$ district)

Gürün ilçesinde ilk olarak monokristal panel kullanılarak 10 MW kurulu güce sahip güneş enerjisi santralinin ekonomik fizibilite çalışması gerçekleştirilmiştir. Kurulum yapılacak arazinin küresel radyasyon miktarı y1llı $1.649 \mathrm{kWh} / \mathrm{m}^{2}$, dir. Panellerin dizi nominal enerjisi 18.232 MWh olarak gerçekleşmektedir. Kayıplar çıkarıldı̆̆ında sistem şebekeye yıllık 16.129 MWh enerji vermektedir. Şekil 13' de Gürün ilçesinde monokristal panellerle oluşturulan santralin enerji kayıp diyagramı görülmektedir. Gürün ilçesindeki diğer çalışmada polikristal panel kullanılarak 9,999 MW kurulu güce sahip güneş enerjisi santralinin ekonomik fizibilite çalışması gerçekleştirilmiştir. Panellerin dizi nominal enerjisi 18.224 MWh olarak gerçekleşmektedir. Kayıplar çıkarıldığında sistem şebekeye yıllık 15.976 MWh enerji vermektedir. Şekil 14' de
Gürün ilçesinde polikristal panellerle oluşturulan santralin enerji kayıp diyagramı görülmektedir.

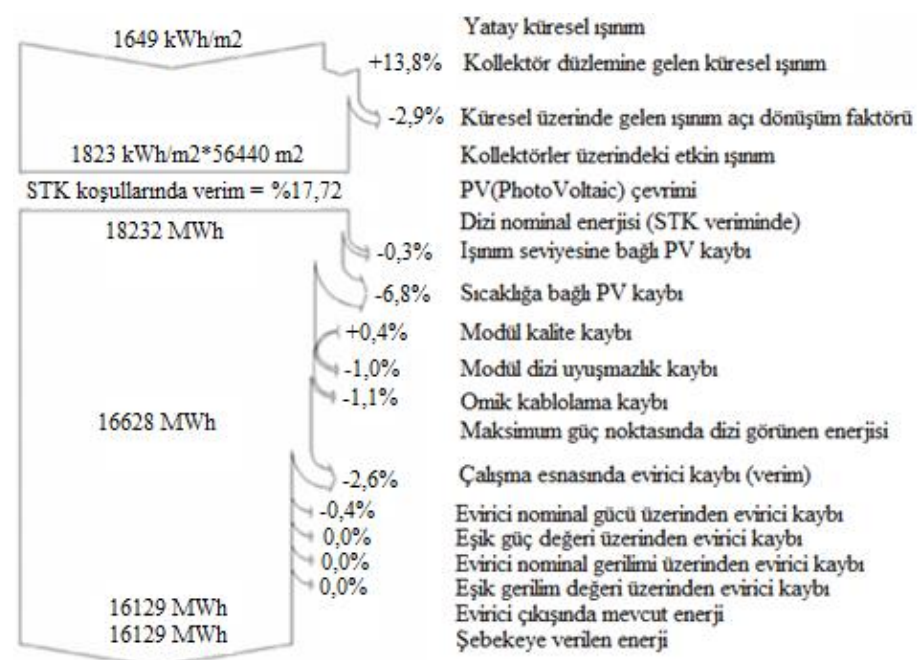

Şekil 13. Gürün ilçesinde monokristal panellerle oluşturulan santralin enerji kayıp diyagramı (Fig 13. Energy loss diagram of the power plant built with monocrystalline panels in Gürün district)

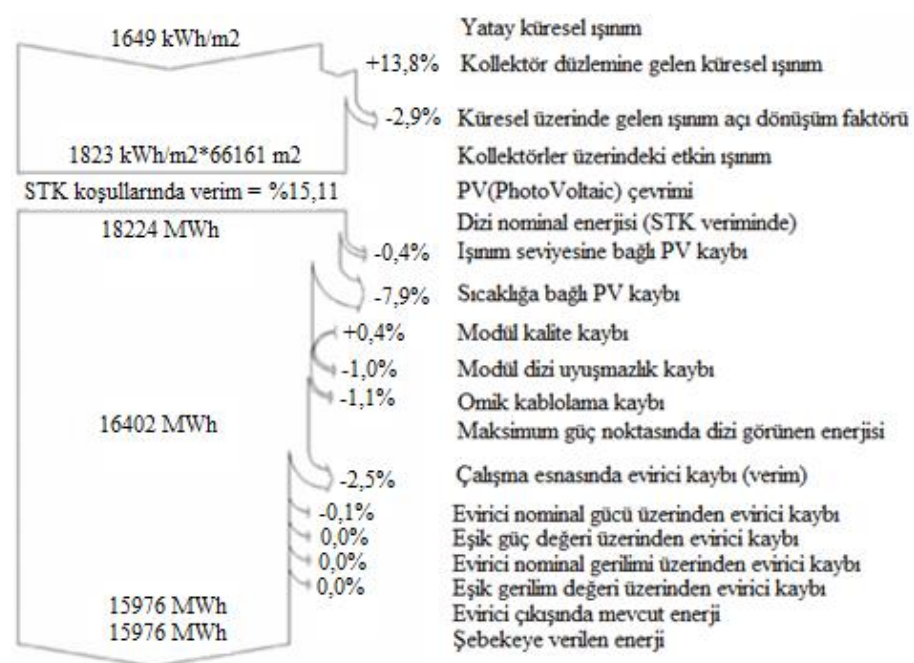

Şekil 14. Gürün ilçesinde polikristal panellerle oluşturulan santralin enerji kayı diyagramı (Fig 14. Energy loss diagram of the power plant built with polycrystalline panels in Gürün district)

Yıldızeli ilçesinde ilk olarak monokristal panel kullanılarak 10 MW kurulu güce sahip güneş enerjisi santralinin ekonomik fizibilite çalışması gerçekleştirilmiştir. Kurulum yapılacak arazinin küresel radyasyon miktarı yıllık $1.561 \mathrm{kWh} / \mathrm{m}^{2}$, dir. Panellerin dizi nominal enerjisi 17.442 MWh olarak gerçekleşmektedir. Kayıplar çıkarıldığında sistem şebekeye y1llık 15.616 MWh enerji vermektedir. Şekil 15' de Yıldızeli ilçesinde monokristal panellerle oluşturulan santralin enerji kayıp diyagramı görülmektedir. Yıldızeli ilçesindeki diğer çalışmada polikristal panel kullanılarak 9,999 MW kurulu güce sahip güneş enerjisi santralinin ekonomik fizibilite çalışması gerçekleştirilmiştir. Panellerin dizi nominal enerjisi 17.435 MWh olarak gerçekleşmektedir. Kayıplar çıkarıldığında sistem şebekeye y1llı 15.453 MWh enerji vermektedir. Şekil 16' da Yıldızeli ilçesinde polikristal panellerle oluşturulan santralin enerji kayıp diyagramı görülmektedir. 


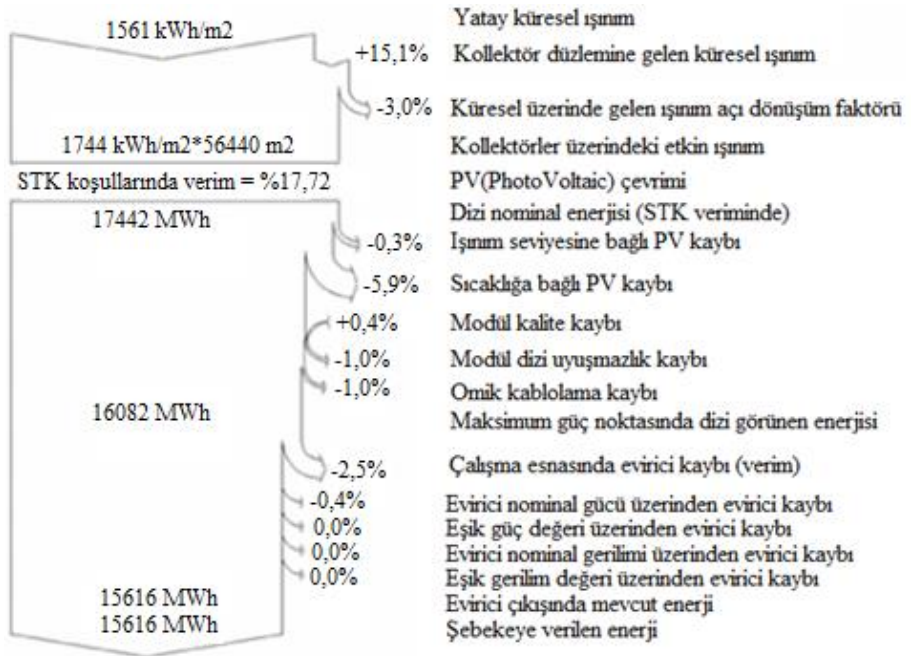

Şekil 15. Yıldızeli ilçesinde monokristal panellerle oluşturulan santralin enerji kayı diyagramı (Fig 15. Energy loss diagram of the power plant built with monocrystalline panels in Ylldızeli district)

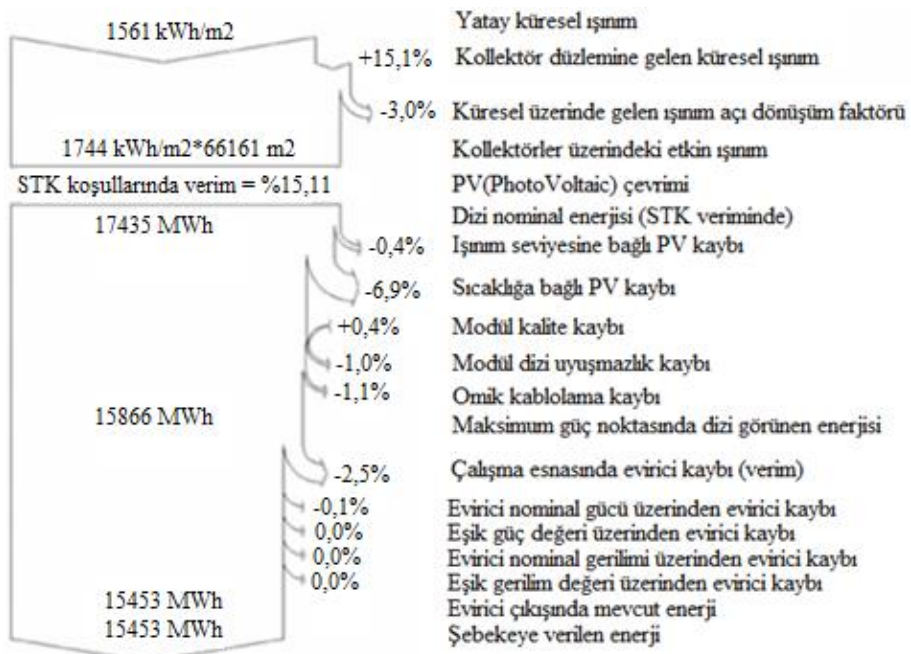

Şekil 16. Yıldızeli ilçesinde polikristal panellerle oluşturulan santralin enerji kayıp diyagramı (Fig 16. Energy loss diagram of the power plant built with polycrystalline panels in Ylldızeli district)

Zara ilçesinde ilk olarak monokristal panel kullanılarak 10 MW kurulu güce sahip güneş enerjisi santralinin ekonomik fizibilite çalışması gerçekleştirilmiştir. Kurulum yapılacak arazinin küresel radyasyon miktarı yıllık $1.518 \mathrm{kWh} / \mathrm{m} 2$ ' dir. Panellerin dizi nominal enerjisi 17.012 MWh olarak gerçekleşmektedir. Kayıplar çıkarıldığında sistem şebekeye yıllık 15.181 MWh enerji vermektedir. Şekil 17' de Zara ilçesinde monokristal panellerle oluşturulan santralin enerji kayıp diyagramı görülmektedir. Zara ilçesindeki diğer çalışmada polikristal panel kullanılarak 9,999 MW kurulu güce sahip güneş enerjisi santralinin ekonomik fizibilite çalışması gerçekleştirilmiştir. Panellerin dizi nominal enerjisi 17.005 MWh olarak gerçekleşmektedir. Kayıplar çıkarıldığında sistem şebekeye yıllık 15.023 MWh enerji vermektedir. Şekil 18' de Zara ilçesinde polikristal panellerle oluşturulan santralin enerji kayıp diyagramı görülmektedir.

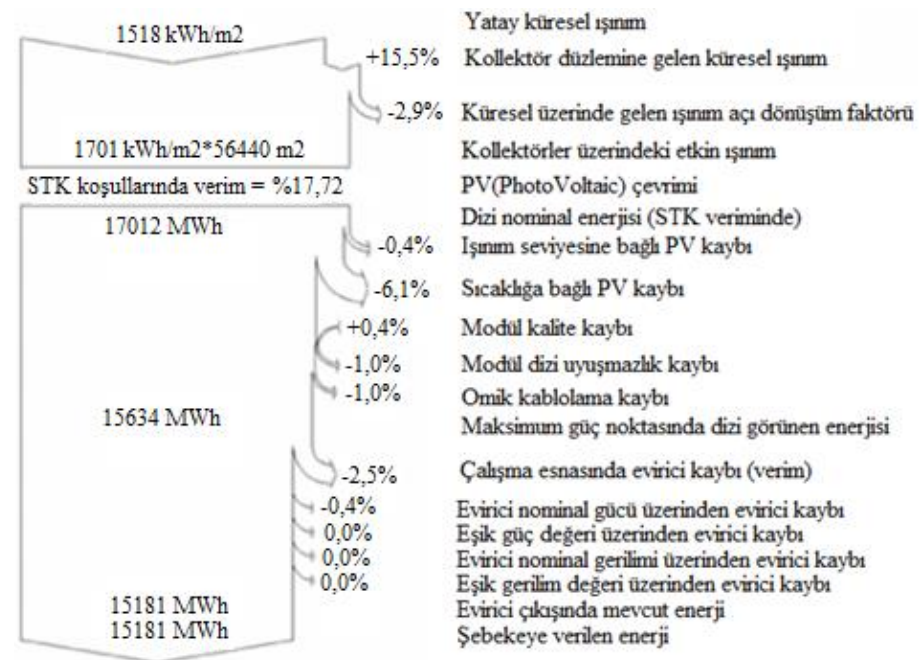

Şekil 17. Zara ilçesinde monokristal panellerle oluşturulan santralin enerji kayı diyagramı (Fig 17. Energy loss diagram of the power plant built with monocrystalline panels in Zara district)

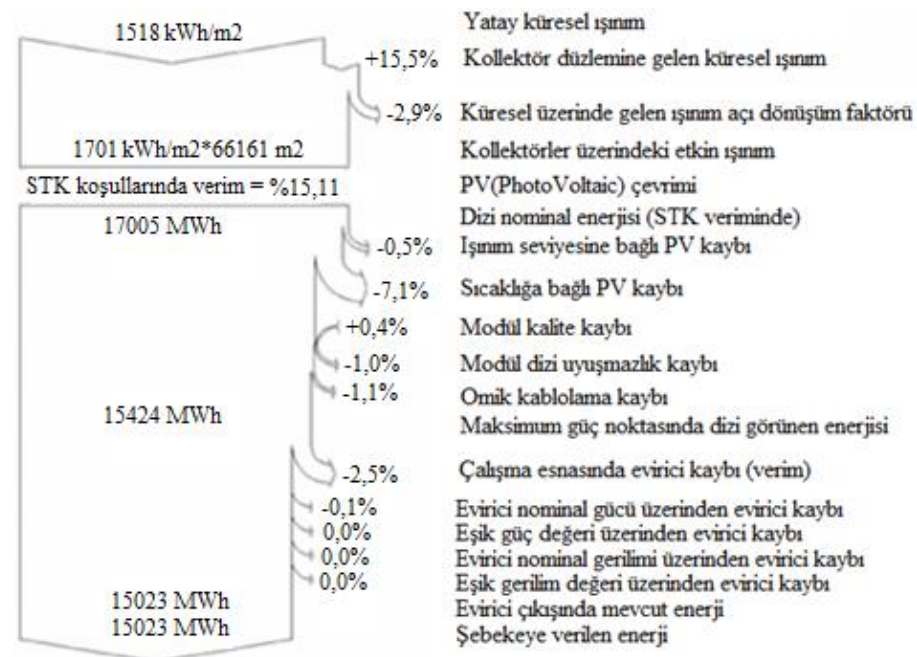

Şekil 18. Zara ilçesinde polikristal panellerle oluşturulan santralin enerji kayıp diyagramı (Fig 18. Energy loss diagram of the power plant built with polycrystalline panels in Zara district)

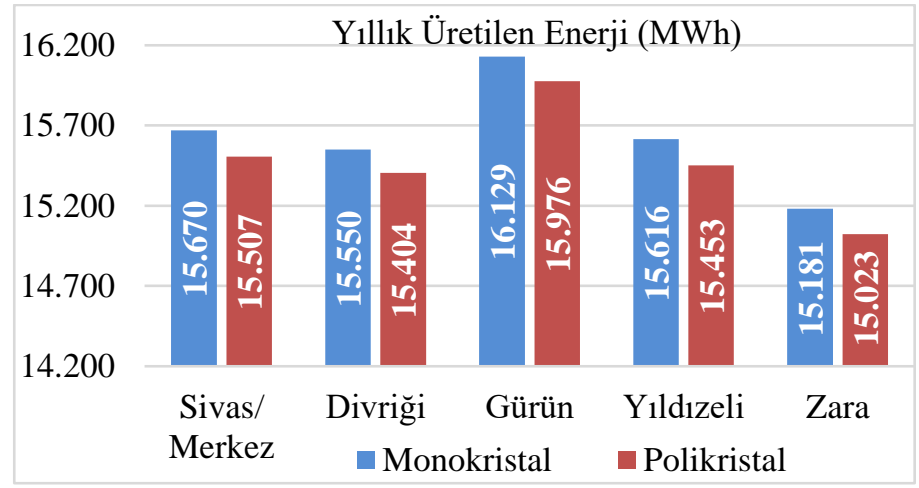

Şekil 19. Ilk yul üretilen yullık enerji (Fig 19. Annual energy generated in the first year)

Şekil 19' da tüm ilçelere ait ilk yıl üretilen yıllık elektrik enerjisi görülmektedir. Yıllık üretilen enerji en fazla Gürün ilçesinde (monokristal için 16.129 MWh, polikristal için 15.976 MWh) en az Zara ilçesinde (monokristal için 15.181 MWh, polikristal için 15.023 MWh) olmaktadır. Bunun sebebi Şekil 7' 
de görüldüğü gibi Gürün ilçesinin küresel 1şınım miktarının en fazla, Zara ilçesinin küresel ışınım miktarının en az olmasıdır.

Santrallerin, banka kredisi alınmadan ve 8 y1l geri ödemeli yıllık \% 8,5 faizle banka kredisi alınarak kurulması durumları incelenmiştir. Santrallerin banka kredisi alınmadan kurulumundaki sonuçlara göre santrallerin geri ödeme süreleri Tablo 5' de verilmiştir. Tablo 5' de görüldüğü gibi polikristal panellerle oluşturulan santrallerin geri ödeme süreleri, monokristal panellerle oluşturulan santrallerin geri ödeme sürelerinden daha kısa olmaktadır. Bunun nedeni Şekil 20' de görüldüğü gibi polikristal panellerle oluşturulan santrallerin yatırım maliyetlerinin daha az olmasıdır. En kısa geri ödeme süresi 4,5 yıl ile Divriği ve Yıldızeli ilçelerinde polikristal paneller ile kurulan santrallerde gözlenmiştir. En uzun geri ödeme süresi ise 6,3 yıl ile Zara ilçesinde monokristal paneller ile kurulan santralde olmuştur. Tablo 6' da kurulan santrallerin PVsyst programından elde edilen performans oranları verilmiştir. Merkez ve Yıldızeli ilçesinde monokristal panellerle kurulan santraller \% 86,9 ile en yüksek performans oranına sahiptirler. En düşük performans oranı \% 85,3 ile Gürün ilçesinde polikristal paneller ile kurulan santralde olmuştur. Tablo 7' de santrallerin birim maliyetleri verilmiştir. En düşük birim maliyet $0,04443 \$ / \mathrm{kWh}$ ile Divriği ilçesinde polikristal panellerle kredi alınmadan kurulan santralde olmaktadır. En yüksek birim maliyet ise 0,06159 $\$ / \mathrm{kWh}$ ile Zara ilçesinde monokristal panellerle kredi alınarak kurulan santralde olmaktadır.

Tablo 5. Santrallerin Geri Ödeme Süreleri (Table 5. Payback Periods of Power Plants)

\begin{tabular}{|c|c|c|}
\hline İlçe Adı & Monokristal & Polikristal \\
\hline Merkez & 5,3 y1l & 5,2 y1l \\
\hline Divriği & 4,6 y1l & $4,5 \mathrm{y} 11$ \\
\hline Gürün & 5,4 y1l & 5,3 y1l \\
\hline Yıldızeli & 4,6 y1l & $4,5 \mathrm{y} 11$ \\
\hline Zara & 6,3 y1l & 6,1 y1l \\
\hline
\end{tabular}

Tablo 6. Santrallerin Performans Oranlarl (Table 6. Performance Ratios of Power Plants)

\begin{tabular}{|c|c|c|}
\hline İlçe Ad $l$ & Monokristal & Polikristal \\
\hline Merkez & $\% 86,9$ & $\% 86,2$ \\
\hline Divriği $i$ & $\% 86,3$ & $\% 85,4$ \\
\hline Gürün & $\% 86,1$ & $\% 85,3$ \\
\hline Yıldızeli & $\% 86,9$ & $\% 86,2$ \\
\hline Zara & $\% 86,7$ & $\% 86,0$ \\
\hline
\end{tabular}

Tablo 7. Santrallerin Birim Maliyetleri (Table 7. Unit Costs of Power Plants)

\begin{tabular}{|c|c|c|c|c|}
\hline \multirow{2}{*}{$\begin{array}{c}\text { Ilçe } \\
\text { Adı }\end{array}$} & \multicolumn{2}{|c|}{$\begin{array}{c}\text { Kredisiz Kurulum } \\
\text { (US\$/kWh) }\end{array}$} & \multicolumn{2}{c|}{$\begin{array}{c}\text { Kredili Kurulum } \\
\text { (US\$/kWh) }\end{array}$} \\
\cline { 2 - 5 } & Monokristal & Polikristal & Monokristal & Polikristal \\
\hline Merkez & 0,04752 & 0,04720 & 0,05634 & 0,5581 \\
\hline Divriği & 0,04486 & 0,04443 & 0,05251 & 0,05185 \\
\hline Gürün & 0,04738 & 0,04702 & 0,05629 & 0,05573 \\
\hline Ylldızeli & 0,04485 & 0,04451 & 0,05254 & 0,05197 \\
\hline Zara & 0,05135 & 0,05105 & 0,06159 & 0,06109 \\
\hline
\end{tabular}

Santrallerin banka kredisi kullanılarak kurulması durumu da incelenmiştir. Santrallerin kurulum maliyetlerinin tamamı, bankadan çekilecek kredi ile karşılanmıştır. Merkez ilçedeki çalışmaların sonuçlarına göre, enerji satışından elde edilen getiri ile ilk 8 yıl banka ödemesi ve işletme giderleri karşılanmakta ayrıca monokristal paneller için ilk 8 yılın sonunda 560.000 \$, polikristal paneller için 864.000 \$ kazanç elde edilmektedir. Santralin 30 yıllık ömrü boyunca monokristal panellerden 17.836.000 \$, polikristal panellerden 17.964.000 \$ toplam kazanç elde edilmektedir. Divriği ilçesinde gerçekleştirilen çalışmaların sonucunda, enerji satışından elde edilen getiri ile ilk 8 yıl banka ödemesi ve işletme giderleri karşılanmakta ayrıca monokristal paneller için ilk 8 yılın sonunda 2.248.000 \$, polikristal paneller için 2.524.000 \$ kazanç elde edileceği tespit edilmiştir. Santralin 30 yıllık ömrü boyunca monokristal panellerden 19.407.000 \$, polikristal panellerden 19.466.000\$ toplam kazanç elde edilmektedir. Gürün ilçesinde gerçekleştirilen çalışmalarda enerji satışından elde edilen getiri ile ilk 8 yıl banka ödemesi ve işletme giderleri karşılanmakta ayrıca monokristal paneller için 514.000 \$, polikristal paneller için 804.000 \$ kazanç elde edilmektedir. Santralin 30 yıllık ömrü boyunca monokristal panellerden $18.457 .000 \$$, polikristal panellerden 18.550.000 \$ toplam kazanç elde edilmektedir. Yıldızeli ilçesinde gerçekleştirilen çalışmalarda enerji satışından elde edilen getiri ile ilk 8 yıl banka ödemesi ve işletme giderleri karşılanmakta ayrıca monokristal paneller için 2.184.000 \$, polikristal paneller için 2.491.000 \$ kazanç elde edilmektedir. Santralin 30 yıllık ömrü boyunca monokristal panellerden 19.386.000 \$, polikristal panellerden 19.522.000 \$ toplam kazanç elde edilmektedir. Zara ilçesinde gerçekleştirilen çalışmalarda enerji satışından elde edilen getiri ile ilk 8 yılın sonunda banka ödemesi ve işletme giderleri karşılanamamakta ve monokristal için toplam 1.480 .000 \$, polikristal için $1.171 .000 \$$ borçlanılmaktadır. 9. y1l ise borç kapatılıp monokristal için 59.000 \$, polikristal için 354.000 \$ getiri sağlanmaktadır. Santralin 30 yıllık ömrü boyunca monokristal panellerden 15.142.000 \$, polikristal panellerden 15.281.000\$ toplam kazanç elde edilmektedir.

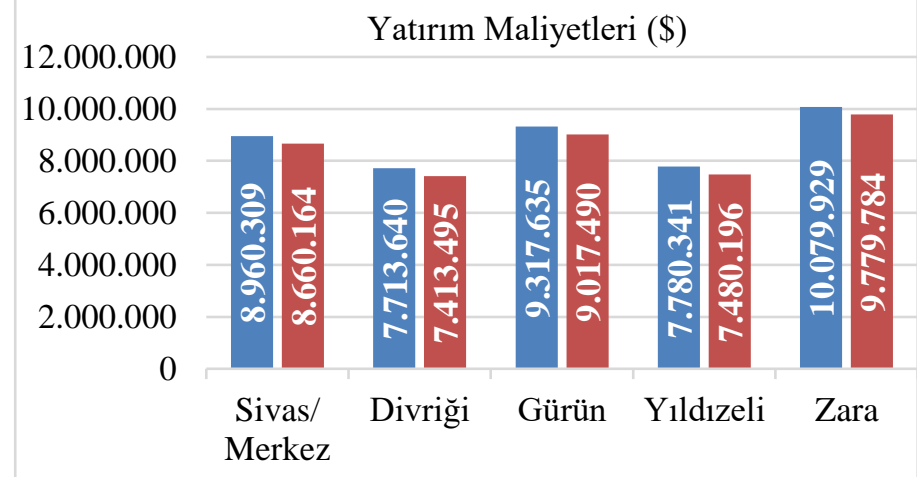

Şekil 20. Yatırım maliyetleri (Fig 20. Investment costs)

Şekil 20' de tüm ilçelere ait yatırım maliyetleri gösterilmektedir. Yatırım maliyetinin en fazla Zara ilçesinde olmasının sebebi bu ilçedeki arazi fiyatlarının yüksek olmasıdır. $\mathrm{Bu}$ çalışma kapsamında santraller tasarlanırken sanayi bölgelerine yakın yerler seçilmiştir. Zara ilçesindeki sanayi bölgesine yakın arazilerin fiyatları da yüksektir. $\mathrm{Bu}$ ilçede yatırım maliyetini azaltmak için santralin, fiyatı daha düşük olan araziye kurulması gerekmektedir. Şekil 21' de tüm ilçelere ait 30 yıllık santral ömrü boyunca kurulum ve işletme masrafları çıkarılmadan enerji satışından elde edilen toplam getiri gösterilmektedir. Burada üretilen enerji miktarı ile orantılı olarak satılan enerji en fazla Gürün ve en az Zara ilçesinde olmaktadır. Şekil 22' de ise 30 yıl boyunca elde edilen getiriden kurulum ve işletme masrafı çıkarıldığında elde edilen kâr gösterilmektedir. Santralin 30 yıllık ömrü boyunca toplam kârı monokristal panellerle Merkez ilçe için 17.836.000 \$, Divriği ilçesi için 
19.407.000 \$, Gürün ilçesi için 18.457.000 \$, Yıldızeli ilçesi için 19.386.000 \$ ve Zara ilçesi için ise 15.142.000 \$ olmaktadır. Polikristal panellerle oluşturulan santralin 30 yıllık toplam kârı Merkez ilçe için 17.964.000 \$, Divriği ilçesi için 19.466.000 \$, Gürün ilçesi için 18.550.000 \$, Y1ldızeli ilçesi için 19.522.000 \$ ve Zara ilçesi için ise 15.281.000 \$ olmaktadır. En fazla kâr monokristal paneller için 19.407.000 \$ ile Divriği ilçesinde, polikristal paneller için 19.522.000 \$ ile Yıldızeli ilçesinde olmaktadir.

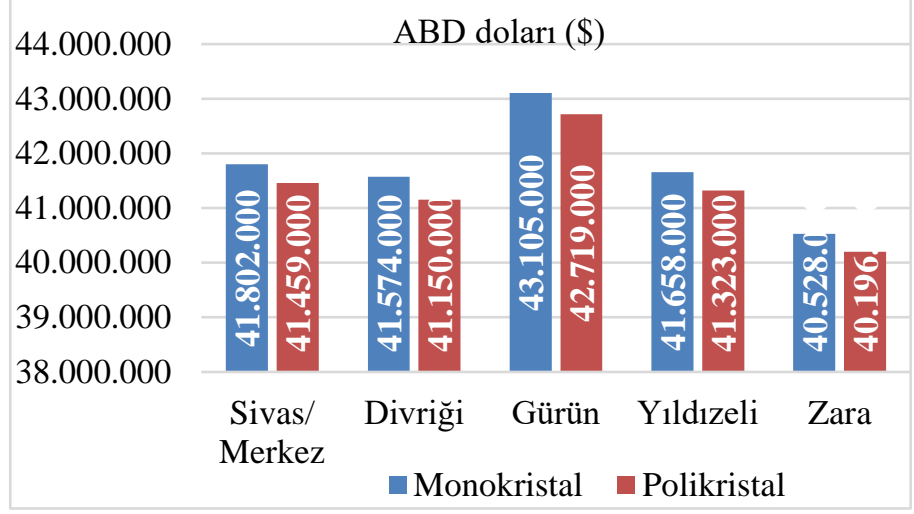

Şekil 21. Santral ömrü boyunca elde edilen getiri (Fig 21. Income over the life of the plant.)

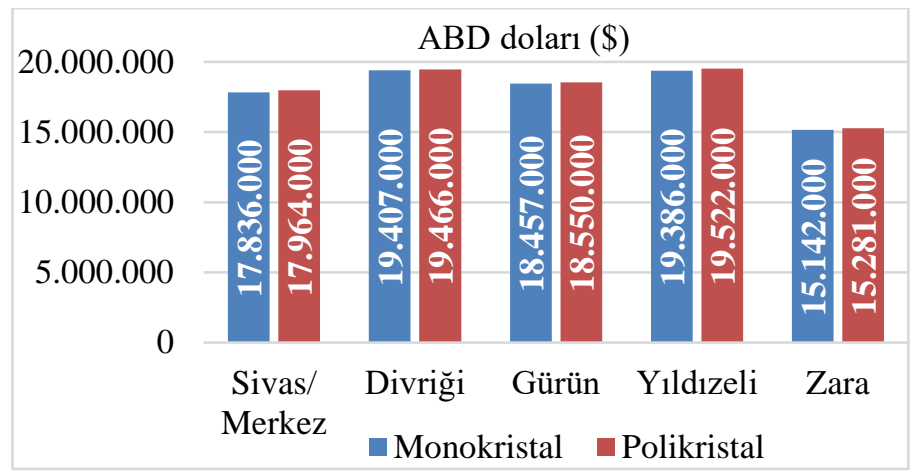

Şekil 22. Santral ömrü boyunca elde edilen kar (Fig 22. Profit over the life of the plant.)

\section{Sonuç}

Fosil yakıtların çevreye verdiği zararlardan dolayı yenilenebilir enerjiden elektrik enerjisi üretimi gittikçe artmaktadır. Ayrıca ülkelerin enerji üretiminde dışa bağlılığını azaltmanın en iyi yolu yenilenebilir enerji yatırımlarıdır. Bu çalışmada Sivas ilinin beş farklı ilçesinde PVsyst programı ile 10 MW gücünde monokristal ve polikristal panellerden oluşan güneş enerji santralleri tasarlanmış ve analiz edilmiştir. Kredi kullanmadan ve 8 yıllık geri ödemeli kredi kullanılması durumları incelenmiștir. Öncelikle banka kredisi alınmadan santrallerin kurulumu analiz edilmiş ve elde edilen sonuçlara göre polikristal panellerle oluşturulan santrallerin geri ödeme süreleri, monokristal panellerin geri ödeme sürelerinden daha kısa olmaktadır. Bunun nedeni polikristal panellerle oluşturulan santrallerin yatırım maliyetlerinin daha az olmasıdır. En kısa geri ödeme süresi Divriği ve Yıldızeli ilçelerinde polikristal paneller ile kurulan santrallerde 4,5 yıl olarak gözlenmiştir. En uzun geri ödeme süresi 6,3 yıl ile Zara ilçesinde monokristal paneller ile kurulan santralde olmuştur. Merkez ve Yıldızeli ilçesinde monokristal panellerle kurulan santraller \% 86,9 ile en yüksek performans oranına sahiptirler. En düşük performans oranı $\%$ 85,3 ile Gürün ilçesinde polikristal paneller ile kurulan santralde olmuştur. En düşük birim maliyet $0,04443 \$ / \mathrm{kWh}$ ile Divriği ilçesinde polikristal panellerle kredi alınmadan kurulan santralde olmaktadır. En yüksek birim maliyet ise 0,06159 \$/kWh ile Zara ilçesinde monokristal panellerle kredi alınarak kurulan santralde olmaktadir.

Her bir santral güneş enerji potansiyeli, enerji üretimi, maliyet, geri ödeme süresi ve karlılık açısından karşılaştırılmıştır. Monokristal panellerin verimi daha yüksek olduğundan dolayı, monokristal panellerle oluşturulan sistemin elektrik enerjisi üretimi polikristal panellere göre daha yüksek olmaktadır. Monokristal panellerle oluşturulan sistemin ilk kuruluş masrafi polikristal panellerle oluşturulan sistemin ilk kuruluş masrafından daha yüksek olmaktadır. İlk yatırım masrafinın düşük olması için polikristal paneller tercih edilebilirken, uzun vadede daha çok getiri için monokristal paneller tercih edilebilir. Maliyetler eklenmeden sadece elektrik üretim miktarına bakıldığında en fazla üretilen elektrik enerjisi Gürün ilçesinde olmaktadır, bunun nedeni bu ilçede küresel ışınım miktarının diğer ilçelere göre en fazla olmasıdır. En az üretilen elektrik enerjisi ise Zara ilçesinde olmaktadır bunun nedeni küresel ışınım miktarının bu ilçede diğer ilçelere göre en az olduğundan dolayıdır. Şekil 22' de görüldüğü gibi gelirlerden maliyetler çıkarıldıktan sonra santral ömrü boyunca elde edilen en çok kar monokristal paneller için 19.407.000 \$ ile Divriği ilçesinde, polikristal paneller için 19.522.000 \$ ile Yıldızeli ilçesinde olmaktadır. Zara ilçesinin arazi fiyatları yüksek olduğu için elde edilen kar düşük çıkmıştır. $\mathrm{O}$ yüzden bu ilçede güneş enerjisi santrali kurulması düşünüldüğünde, fiyatı ucuz bir araziye kurulması daha doğru bir çözüm olacaktır.

$\mathrm{Bu}$ çalışmada $10 \mathrm{MW}$ gücünde güneş enerjisi santrali kurulumu ve analizi Sivas ilinin beş ilçesinde yapılmış, bütün ilçelerinde yapılmamıştır. Bundan sonraki çalışmalarda diğer ilçelerde de farklı güçlerde güneş enerji santrali kurulumu ve analizinin yapılması Sivas ilinde kurulabilecek güneş enerji santralleri için faydalı olacaktır. Ayrıca bu çalışmanın devamında daha uzun vadede ve daha kısa vadede kredi çekilerek santrallerin kurulması durumları analiz edilebilir. Her bir durum için geri ödeme süreleri ve birim maliyetler belirlenebilir. Böylelikle Sivas ilinde güneş enerjisi santrali kurulumu ve analizi ile ilgili daha çok bilgi elde edilmiş olur ve bu sayede bu bölgede yatırımlar artabilir. Bu konudaki çalışmalara elektrik enerjisi iletim maliyetleri de eklenebilir. Bir bölgede üretilen elektrik enerjisinin daha uzak bölgelerde kullanılması durumu incelenebilir ve böylelikle sistemdeki hat kayıpları ve sistemin verimi hesaplanabilir.

\section{Kaynakça}

Akboy, E. (2019). Yüksek Güç Faktörlü Şebeke Bağlı Bir PV Sistemin Modellenmesi ve Farklı Işınımlar Altında Kontrolü. Avrupa Bilim ve Teknoloji Dergisi, (17), 794-802.

Akcan, E., Kuncan, M., \& Minaz, M.R. (2020). PVsyst Yazılımı ile $30 \mathrm{~kW}$ Şebekeye Bağlı Fotovoltaik Sistemin Modellenmesi ve Simülasyonu. Avrupa Bilim ve Teknoloji Dergisi, (18), 248-261.

Akyazı, Ö., Şahin, E. \& Kahveci, D. C. (2019). Fotovoltaik Panel ve Şebeke Entegrasyonlu Akıllı Sokak Lambası Tasarımı ve Uygulaması. Avrupa Bilim ve Teknoloji Dergisi, (Özel Sayı), 356-360.

Aldudak, M. (2018). Economic Analysis and Efficiency Evaluation of PV Systems in Different Cities of Turkey. 
Yüksek Lisans Tezi. Bahçeşehir Üniversitesi, Fen Bilimleri Enstitüsü, 94s, İstanbul.

Barua, S., Prasath, R. A., \& Boruah, D. (2017). Rooftop Solar Photovoltaic System Design and Assessment for The Academic Campus Using PVsyst Software. International Journal of Electronics and Electrical Engineering, 5(1), 7683.

Cavalcante, M. M., de Souza Silva, J. L., Villalva, M. G., \& Lins, M. P. F. (2019). Performance Analysis of a Solar Photovoltaic Power Plant. 2019 IEEE PES Innovative Smart Grid Technologies Conference-Latin America (1-5).

Cebeci, S. (2017). Türkiye'de Güneş Enerjisinden Elektrik Üretim Potansiyelinin Değerlendirilmesi. T.C. Kalkınma Bakanlığı, Uzmanlık Tezi, Yayın No: 2977, Ankara.

Çekirdek, M. (2017). Fotovoltaik Güç Santrallerinin TeknoEkonomik Analizi: Türkiye Örneği. Yüksek Lisans Tezi. Dokuz Eylül Üniversitesi, Fen Bilimleri Enstitüsü, 89s, İzmir.

Dandıl, E. \& Gürgen, E. (2019). Yapay Sinir Ağları Kullanılarak Fotovoltaik Panel Güç Çıkışlarının Tahmini ve Sezgisel Algoritmalar ile Karşılaştırılması. Avrupa Bilim ve Teknoloji Dergisi, (16), 146-158.

Erdoğan, S. (2020). Enerji, Çevre ve Sera Gazları. Çankırı Karatekin Üniversitesi İktisadi ve İdari Bilimler Fakültesi Dergisi, 10(1), 277-303.

Erkınay, P. U. (2012). Yenilenebilir Enerji Kaynaklarından Rüzgâr Enerjisinin Türkiye'de Binalarda Kullanımı Üzerine Bir İnceleme. Yüksek Lisans Tezi. Çukurova Üniversitesi, Fen Bilimleri Enstitüsü, 101s, Adana.

Eyigün, S. (2010). Türkiye' nin Farklı Bölgelerinde Kurulacak Fotovoltaik Santrallerin Teknik ve Ekonomik Açıdan İncelenmesi. Yüksek Lisans Tezi. İstanbul Teknik Üniversitesi, Enerji Enstitüsü, 125s, İstanbul.

Girgin, M. H. (2011). Bir Fotovoltaik Güneş Enerjisi Santralinin Fizibilitesi, Karaman Bölgesinde 5 MW'lık Güneş Enerjisi Santrali için Enerji Üretim Değerlendirmesi ve Ekonomik Analizi. Yüksek Lisans Tezi. İstanbul Teknik Üniversitesi, Enerji Enstitüsü, 223s, İstanbul.

Güner, S. \& Muharremoğlu, A. (2020). Bir Havalimanı Otoparkına Kurulabilecek Fotovoltaik Üretim Sisteminin Tasarımı ve Enerji Analizi. Avrupa Bilim ve Teknoloji Dergisi, (19), 182-188.

Huld, T. Global Irradiation and Solar Electricity Potential, http://re.jrc.ec.europa.eu/pvg_download/map_pdfs/G_hor_T R.png Erişim Tarihi: 19.09.2020

Kahraman, M. Ü. (2018). Kütahya Bölgesi Güneş ve Rüzgâr Enerji Potansiyellerinin Tekno-Ekonomik Analizi. Yüksek Lisans Tezi. Dumlupınar Üniversitesi, Fen Bilimleri Enstitüsü, 135s, Kütahya.

Keskin, E. (2012). Türkiye İklim Koşullarında Fotovoltaik Güç Sistemlerinin Tasarımı ve Maliyet Analizi. Yüksek Lisans Tezi. Hacettepe Üniversitesi, Fen Bilimleri Enstitüsü, 114s, Ankara.

Koçak, M. E. (2018). Büyükçekmece İlçesindeki Güneş Enerji Santralinin Tasarımı ve Ekonomik Analizi. Yüksek Lisans Tezi. Sakarya Üniversitesi, Fen Bilimleri Enstitüsü, 129s, Sakarya.

Kumar, N. M., Kumar, M. R., Rejoice, P. R., \& Mathew, M. (2017). Performance Analysis of $100 \mathrm{kWp}$ Grid Connected Si-poly Photovoltaic System Using PVsyst Simulation Tool. Energy Procedia, 117, 180-189.

Ramoliya, J. V. (2015). Performance Evaluation of Gridconnected Solar Photovoltaic Plant Using PVSYST
Software. Journal of Emerging Technologies and Innovative Research (JETIR), 2(2), 372-378.

Rio Declaration on Environment and Development, (1992). https://legal.un.org/avl/pdf/ha/dunche/rio_ph_e.pdf Erişim Tarihi: 19.09 .2020

Rout, K. C., \& Kulkarni, P. S. (2020). Design and Performance Evaluation of Proposed $2 \mathrm{~kW}$ Solar PV Rooftop on Grid System in Odisha Using PVsyst. 2020 IEEE International Students' Conference on Electrical, Electronics and Computer Science (SCEECS) (1-6).

Saraswat, R. (2016). Comparative Performance Evaluation of Solar PV Modules from Different Manufacturers in India by Using PVsyst. 2016 IEEE 1st International Conference on Power Electronics, Intelligent Control and Energy Systems (ICPEICES) (1-3).

Sarı, V. \& Özyiğit, F. Y. (2020). Sivas Cumhuriyet Üniversitesi Yerleşkesinde Güneş Enerjisi Santralinin Ekonomik Analizi. Dokuz Eylül Üniversitesi Fen ve Mühendislik Dergisi, 22(65), 517-526.

Satish, M., Santhosh, S., \& Yadav, A. (2020). Simulation of a Dubai Based 200 KW Power Plant Using PVsyst Software. 2020 7th International Conference on Signal Processing and Integrated Networks (SPIN) (824-827).

Saxena, G., \& Gidwani, L. (2018). Estimation of Energy Production of Grid Connected Rooftop Solar Photovoltaic System at Nagar Nigam Kota, Rajasthan. 2018 3rd International Innovative Applications of Computational Intelligence on Power, Energy and Controls with their Impact on Humanity (CIPECH) (45-49).

Sivas Belediyesi. Rayiç Sorgulama. https://online.sivas.bel.tr/Rayic/Index Erişim Tarihi: 05.10 .2020

Solar Design Tool, Canadian Solar CS6X-290P, http://www.solardesigntool.com/components/module-panelsolar/Canadian-Solar/3850/CS6X-290P/specification-datasheet.html

Solar Design Tool, Trina Solar TSM-290DD05A.08(II), http://www.solardesigntool.com/components/module-panelsolar/Trina-Solar/4926/TSM-290DD05A-08-II/specification-data-sheet.html

Start Solar, System Types, http://startsolar.co.in/systemtypes/\#on-grid Erişim Tarihi: 19.09.2020

T.C. Enerji ve Tabii Kaynaklar Bakanlığı, Enerji İşleri Genel Müdürlügü̈, Güneş Enerjisi Potansiyel Atlası (GEPA), http://www.yegm.gov.tr/MyCalculator/pages/58.aspx Erişim Tarihi: 19.09.2020

T.C. Enerji ve Tabii Kaynaklar Bakanlığı, Enerji İşleri Genel Müdürlüğü. Güneş Enerjisi ve Teknolojileri, http://www.yegm.gov.tr/yenilenebilir/g enj tekno.aspx Erişim Tarihi: 19.09.2020

T.C. Tarım ve Orman Bakanlığı Meteoroloji Genel Müdürlüğü, Aylık Ortalama Güneşlenme Süresi, https://www.mgm.gov.tr/kurumici/turkiye-guneslenmesuresi.aspx Erişim Tarihi: 19.09.2020

T.C. Tarım ve Orman Bakanlığı Meteoroloji Genel Müdürlüğü, Resmi İstatistikler, https://www.mgm.gov.tr/veridegerlendirme/il-ve-ilceleristatistik.aspx?k=A\&m=SIVAS Erişim Tarihi: 19.09.2020

T.C. Tarım ve Orman Bakanlığg Meteoroloji Genel Müdürlüğü, Türkiye Global Güneş Radyasyonu Uzun Yıllar Ortalaması (2004-2018) Heliosat Model Ürünleri, https://www.mgm.gov.tr/kurumici/radyasyon_iller.aspx Erişim Tarihi: 19.09.2020 
T.C. Tarım ve Orman Bakanlığı Meteoroloji Genel Müdürlüğü, Türkiye Günlük Güneşlenme Süreleri, https://www.mgm.gov.tr/FILES/resmiistatistikler/parametreAnalizi/Turkiye-Gunluk-GuneslenmeSuresi.pdf Erişim Tarihi: 19.09.2020

Tallab, R., \& Malek, A. (2015). Predict System Efficiency of 1 MWc Photovoltaic Power Plant Interconnected to The Distribution Network Using PVsyst Software. 2015 3rd International Renewable and Sustainable Energy Conference (IRSEC) (1-4).

Tekkale, G. (2018). Türkiye' nin Çeşitli İllerinde Yapılacak Arazi Tipi Lisanssız Güneş Enerjisi Santrali Yatırımlarının Teknik ve Finansal Analizi. Yüksek Lisans Tezi. İstanbul Teknik Üniversitesi, Enerji Enstitüsü, 137s, İstanbul.

Türkdoğan, S., Mercan, M.T.\& Çatal, T. (2020). Şebekeden Bağımsız Hibrit Enerji Sistemleri Kullanılarak 40 Hanelik
Bir Topluluğun Elektrik ve Termal Yük İhtiyacının Karşılanması: Teknik ve Ekonomik Analizleri. Avrupa Bilim ve Teknoloji Dergisi, (18), 476-485.

Türkmen, S. (2020). Enerji Trilemmas1: Türkiye Üzerine Bir Değerlendirme. Avrasya Sosyal ve Ekonomi Araştırmalar Dergisi, 7(6), 299-309.

Yağl1, H. \& Koç, Y. (2020). Gaziantep Bölgesi İçin Güneş Enerjisinden Elektrik Üretiminde Kurulacak Panellerin Optimum Eğim Açılarının Belirlenmesi. Avrupa Bilim ve Teknoloji Dergisi, (19), 475-483. 